\title{
NAKNADA ŠTETE PROUZROČENE CIJEPLJENJEM
}

Doc. dr. sc. Katarina Knol Radoja*

\author{
UDK 351.774.7-053.2(497.5) \\ https://doi.org/10.30925/zpfsr.39.1.17 \\ Ur.: 15. siječnja 2018. \\ Pr.: 19. veljače 2018. \\ Pregledni znanstveni rad
}

\section{Sažetak}

Preporuka većine medicinskih stručnjaka je redovita preventivna zaštita od zaraznih bolesti, ponajprije putem cijepljenja. Ipak, kao i svaki drugi medicinski postupak i ovaj sa sobom nosi određene rizike, koji ponekad mogu biti i fatalni. U tom slučaju oštećeni pojedinac i/ili članovi njegove obitelji, pod određenim uvjetima, mogu imati pravo na naknadu štete. Međutim, kada do obeštećenja pokušaju doći sudskim putem, suočavaju se s dugotrajnim i skupim postupkom dokazivanja uzročne veze između štete u obliku bolesti ili smrti i primljenog cjepiva. Osim nepogodnosti za oštećenu stranu, ovi sudski postupci često imaju negativni publicitet $i$ veliki financijski teret tuženoj strani zbog čega je dolazilo i do zastoja u opskrbi cjepivima. Zbog toga su u nizu država osmišljeni programi naknade štete za teške ozljede ili smrt zbog nuspojava cijepljenja. Cilj je istraživanja stoga analiza i preporuka programa naknade štete zbog nuspojava cijepljenja $i$ u odnosu na često dugotrajnu i skupu građansku parnicu, alternativnog načina obeštećenja. Osim zbog racionalizacije troškova $i$ smanjenja opterećenosti sudova, uvođenje programa naknade štete zbog nuspojava cijepljenja u Republici Hrvatskoj posebno je preporučljivo i jer je u njoj cijepljenje zakonski propisano kao obvezatno. Drugim riječima, iako pacijenti u Republici Hrvatskoj imaju opće pravo na informirani pristanak prije medicinskog zahvata, kada je u pitanju preventivni zahvat cijepljenja nemaju pravo izbora. Nadalje, pri oformljivanju tijela koje vodi program valja ostati oprezan te ga sastaviti od stručnjaka s različitih područja zanimanja, kako bi mogli objektivno sagledati štetni događaj iz svih perspektiva, a ne samo pogodujući jednoj strani.

Ključne riječi: alternativno rješavanje sporova, programi naknade štete zbog nuspojava cijepljenja, medicinski sporovi, informirani pristanak.

* Dr. sc. Katarina Knol Radoja, docentica Pravnog fakulteta Sveučilišta J. J. Strossmayera u Osijeku;kknol@pravos.hr. 


\section{1. $U V O D$}

Niti jedan medicinski postupak nije potpuno bez rizika. Cjepiva, iako dizajnirana za (preventivnu) zaštitu od bolesti, ${ }^{1}$ mogu uzrokovati nuspojave koje se kreću od blagih do vrlo ozbiljnih. Najčešće nuspojave cijepljenja su bol, temperatura, oticanje i crvenilo na mjestu uboda. Iako su ozbiljne nuspojave rjeđe, one uključuju po život opasne alergijske reakcije, epileptične napadaje, upalu mozga, multiplu sklerozu, reumatoidni artritis pa čak i smrt. U stručnoj i znanstvenoj literaturi često se ističe da su na razini stanovništva ti rizici mali i uravnoteženi s prednostima populacijske imunizacije (tzv. imunitet krda). ${ }^{2}$

U teoriji se dakle, učinkovitost populacijskog imuniteta, temelji na imunizaciji velikog broja pojedinaca unutar populacije. Dovoljno velikom procijepljenošću mogućnost širenja zaraze se smanjuje, a time se indirektno osigurava zaštita osoba koje se iz određenih medicinski opravdanih razloga ne smiju cijepiti. ${ }^{3}$ Zagovornici teorije o imunitetu krda zbog toga smatraju da se u civiliziranom društvu, životi pojedinaca međusobno isprepliću i gotovo je nemoguće da odluke i ponašanje pojedinca utječe samo na njegove osobne interese bez zadiranja $u$ interese drugih osoba, ${ }^{4}$ ne ostavljajući im time mogućnost izbora hoće li se cijepiti ili ne.

Međutim, to znači da pojedinac povremeno snosi veliki teret za dobrobit ostatka populacije. U Republici Hrvatskoj je za 2014. godinu prijavljeno 155 nuspojava nakon cijepljenja, za 2015. godinu je prijavljeno 148 nuspojava, dok je za 2016. godinu prijavljeno 165 nuspojava. ${ }^{5}$ Većina tih službeno prijavljenih nuspojava bila je blaga u vidu povišene temperature i oteknuća mjesta uboda. Iako su teške nuspojave cijepljenja rijetke, ako do njih ipak dođe, postojanje razrađenog sustava obeštećenja iznimno je važno za uspjeh politike imunizacije i održavanje povjerenja javnosti. Naime, nuspojave povezane s cjepivom rjeđe se pojavljuju zbog nepažnje i najčešće nema jednostavnog načina za dokazati nečiju krivnju. ${ }^{6}$ Kada pojedinac pokuša dobiti

1 Pretpostavka je da je upravo cijepljenje utjecalo na znatno smanjenje broja oboljelih i smrtni ishod od zaraznih bolesti. V. State of the world's vaccines and immunization, 3rd ed. Geneva: World Health Organization; 2009.; dostupno na: http://whqlibdoc.who.int/ publications/2009/9789241563864_eng.pdf, pristupljeno: 23. studenog 2017.

2 Fine, P., Eames, K., Heymann, D. L., Clinical Infectious Diseases, vol. 52., br. 7., 2011., str. 911-916; Mello, M. M., Rationalizing Vaccine Injury Compensation, Bioethics, vol. 22., br. 1., 2008., str. 32- 42 .

3 Više v. Fine, P., Eames, K., Heymann, D. L., Herd Immunity: A Rough Guide, Clin. Infect. Dis., vol. 52., br. 7., 2011., str. 911-916.

4 Silverman, R. D., May, T., Private Choice Versus Public Health: Religion, Morality, and Childhood Vaccination Law, U. Md. L. J. Race Relig. Gender \& Class, vol. 1., 2001., str. 205-521, str. 512.

5 Službeni podatci o prijavljenim nuspojavama cijepljenja mogu se pronaći na internetskim stranicama Hrvatskog zavoda za javno zdravstvo. Dostupno na: https://www.hzjz.hr/sluzbaepidemiologija-zarazne-bolesti/nuspojave-cijepljenja-u-hrvatskoj/, pristupljeno 21 . veljače 2018.

6 Više v. Looker, C., Kelly, H., No-fault Compensation Following Adverse Events Attributed to Vaccination: A Review of International Programmes, Bulletin of the World Health Organization, 2011., str. 371-378; dostupno na: http://www.who.int/bulletin/volumes/89/5/10-081901/en/, pristupljeno: 29. rujna 2017. 
sudskim putem obeštećenje za svoju štetu ili štetu koju je pretrpio bliski član obitelji, suočava se s dugotrajnim i skupim postupkom dokazivanja pred sudom. Ovi su sudski postupci iznimno financijski i emocionalno iscrpljujući, ponajprije zbog teške dokazivosti uzročne veze između cijepljenja i štete, budući da ista često nastupa tek nakon nekoliko mjeseci. ${ }^{7}$

Zbog toga su u nizu država osmišljeni programi naknade štete za teške ozljede ili smrt prouzročene cijepljenjem. Programi su pokrenuti ponajprije zbog uvjerenja da država ima posebnu odgovornost prema onima koji su ozlijeđeni pravilno proizvedenim i ispravno primijenjenim cjepivima koja se koriste za očuvanje javnog zdravlja. Administrativno, većina programa naknade upravlja se putem nekoga stručnog vladinog tijela, uključujući donošenje odluke o prihvaćanju i visini naknade. ${ }^{8}$ Podobnost primatelja naknade može ovisiti o državljanstvu, prebivalištu, dobi, kategoriji cjepiva (obvezno ili preporučeno), zadovoljavanju određenih vremenskih okvira za podnošenje zahtjeva itd. Dokazivanje stvarne uzročnosti neke ozljede kao nuspojave cijepljenja iznimno je teško. Odluka se uglavnom temelji na vjerojatnosti ravnoteže s prevagom za, u odnosu na ne. ${ }^{9}$ Sve države koje imaju neki oblik programa naknade štete zahtijevaju dugotrajan učinak nuspojava (više od šest mjeseci), a naknada najčešće obuhvaća medicinske troškove te troškove zbog invaliditeta ili smrti. Financiranje se u pravilu vrši iz državnog proračuna, pri čemu neki programi imaju potporu nižih državnih tijela ili proizvođača cjepiva.

Nakon niza desetljeća, čini se da su danas u sve više država programi naknade štete prouzročene cijepljenjem sve prihvaćenija komponenta programa imunizacije. S obzirom na to, imamo bolje razumijevanje njihove svrhe, zakonskih okvira, postupka i ishoda iz čega se može puno toga naučiti. Cilj je istraživanja stoga analiza i preporuka programa naknade štete zbog nuspojava cijepljenja, u odnosu na često dugotrajnu i skupu građansku parnicu, alternativnog načina obeštećenja. Osim zbog očiglednih prednosti izvansudskih načina rješavanja spora, uvođenje programa naknade štete zbog nuspojava cijepljenja u Republici Hrvatskoj posebno je preporučljivo i jer je u njoj Zakonom o zaštiti pučanstva od zaraznih bolesti ${ }^{10}$ cijepljenje propisano kao obvezatno, a i problem opadanja razine povjerenja građana u postupak imunizacije više nije nezanemariv.

\section{INFORMIRANI PRISTANAK I (NE)PRAVO NA ODBIJANJE MEDICINSKOG POSTUPKA}

Ustav Republike Hrvatske ${ }^{11}$ u članku 35. propisuje: "Svakom se jamči štovanje i pravna zaštita njegova osobnog i obiteljskog života, dostojanstva, ugleda i časti."

7 Keelan, J., Wilson, K., Balancing Vaccine Science and National Policy Objectives: Lessons From the National Vaccine Injury Compensation Program Omnibus Autism Proceedings, Am. J. Public Health. vol. 101., br. 11., 2011., str. 2016-2021.

8 Evans, G., Vaccine injury compensation programs worldwide, Vaccine, vol. 17., Supplement 3., 1999., str. 25-35.

9 Ibid.

10 Zakon o zaštiti pučanstva od zaraznih bolesti, Narodne novine, br. 79/07., 113/08., 43/09.

11 Ustav Republike Hrvatske, Narodne novine, br. 56/90., 135/97., 113/00., 28/01., 76/10., 5/14. 
U članku 64. propisuje: "Roditelji su dužni odgajati, uzdržavati i školovati djecu te imaju pravo i slobodu da samostalno odlučuju o odgoju djece." Obiteljski zakon ${ }^{12}$ također propisuje niz temeljnih načela i to: u članku 6. temeljem kojeg "Roditelji prije svih imaju pravo, dužnost i odgovornost živjeti sa svojim djetetom i skrbiti se o djetetu, a pomoć im se pruža i intervenira samo u slučaju potrebe" te u članku 7. sukladno kojem su "Mjere kojima se zadire u obiteljski život prihvatljive ako su nužne te se njihova svrha ne može ostvariti poduzimanjem blažih mjera uključujući i preventivnu pomoć, odnosno potporu obitelji." Roditeljsku skrb Obiteljski zakon definira u članku 91/1. na sljedeći način: "Roditeljsku skrb čine odgovornosti, dužnosti i prava roditelja, u svrhu zaštite i promicanja djetetovih osobnih i imovinskih prava te dobrobiti. Roditeljsku skrb roditelji su dužni ostvarivati u skladu s djetetovim razvojnim potrebama i mogućnostima." Nadalje, u članku 92/1. se navodi: “U sadržaj roditeljske skrbi ulazi pravo i dužnost zaštite osobnih prava djeteta na zdravlje, razvoj, njegu i zaštitu, odgoj i obrazovanje, ostvarivanje osobnih odnosa i određivanje mjesta stanovanja" te sukladno odredbi članka 93/1. "Roditelji su dužni i odgovorni skrbiti se o zdravlju djeteta te mu omogućiti korištenje mjera za čuvanje, unapređenje i vraćanje zdravlja, sukladno propisima kojima se uređuje zdravstvo i zahtjevima medicinske znanosti."

Da bi pojedinac, skrbnik ili roditelji za svoje dijete, mogli, u okviru svojeg prava i obveze skrbiti za njegovo zdravlje i dati pristanak na bilo koji medicinski zahvat nužno je da su o tomu u potpunosti obaviješteni. ${ }^{13}$ Informirani pristanak izjava je kojom se pristaje na određeni medicinski zahvat, primjerice operacija, koja se temelji na potpunoj obaviještenosti o činjenicama potrebnim za donošenje svjesne odluke, kao što su rizici i postojanje alternativnih mogućnosti. ${ }^{14}$

Liječnici su obvezni informirati pacijenta o bilo kakvomu razumno predvidljivom riziku od štete koja bi mogla proizaći iz predloženog liječenja. Obavještavanje se mora pružiti tako da pacijent, provodeći uobičajenu brigu o vlastitoj dobrobiti i suočen s izborom predloženog ili eventualno alternativnog tretmana, može izvršiti razumnu prosudbu balansirajući moguće rizike s mogućim dobrobitima. ${ }^{15}$ Informirani pristanak je, dakle sporazum da se nešto učini, odnosno dopusti, da se učini tek nakon što su poznate sve relevantne činjenice. Sporazum se može postići samo ako su obje stranke u potpunosti iznijele sve bitno za taj sporazum.

Pravo pacijenta na suodlučivanje regulirano je međunarodnim i nacionalnim propisima. Međunarodni ugovor koji uređuje to pravo pacijenata je Konvencija o ljudskim pravima i biomedicini ${ }^{16}$ iz 1997. godine. Članak 5. te Konvencije propisuje da se medicinski zahvat može provesti samo nakon što je pacijent dao slobodan i informirani pristanak. Osim toga, $u$ istom se članku navodi i da pacijent mora biti

12 Obiteljski zakon, Narodne novine, br. 116/03., 17/04., 136/04., 107/07., 57/11., 61/11., 25/13., 75/14., 5/15.

13 Legal dictionary, dostupno na: http://legal-dictionary.thefreedictionary.com/Informed+Consent, pristupljeno: 11. rujna 2017.

14 Ibid.

15 Ibid.

16 Konvencija o ljudskim pravima i biomedicini, Narodne novine, Međunarodni ugovori, br. $13 / 03$. 
obaviješten o svrsi i prirodi postupka, kao i o mogućim posljedicama i rizicima te da osoba može u svakom trenutku povući svoj pristanak.

U Republici Hrvatskoj pravo na informirani pristanak regulirano je ponajprije Zakonom o pravima pacijenata. ${ }^{17}$ Također je tu važan i Kodeks medicinske etike i deontologije ${ }^{18}$ Hrvatske liječničke komore. Sukladno članku 8. Zakona o pravima pacijenata, pacijent ima, između ostalog, pravo na potpunu obaviještenost o svome zdravstvenom stanju, uključujući medicinsku procjenu rezultata i ishoda određenoga dijagnostičkog ili terapijskog postupka, preporučenim pregledima i zahvatima te planiranim datumima za njihovo obavljanje, mogućim prednostima i rizicima obavljanja ili neobavljanja preporučenih pregleda i zahvata, svome pravu na odlučivanje o preporučenim pregledima ili zahvatima, kao i mogućim zamjenama za preporučene postupke.

Pacijent ima pravo dobiti obavijesti na način koji mu je razumljiv s obzirom na dob, obrazovanje i mentalne sposobnosti. Stoga se rizici svih medicinskih postupaka, pa tako i oni povezani s nuspojavama cjepiva, ne bi smjeli nametnuti pojedincima bez njihova pristanka. ${ }^{19}$ Pristanak pacijenta na medicinski postupak mora biti utemeljen na potpunoj obaviještenosti o svim mogućim posljedicama, osim u izvanrednim slučajevima kada se taj pristanak ne može dobiti. Liječnik koji ne iznese sve loše, kao i dobre strane postupka, riskira opasnost tužbe, ako nešto pođe po zlu..$^{20}$

Ipak, u nekim državama unatoč pravu na informiranost o medicinskom postupku koji se treba provesti na nekom pojedincu, kada je u pitanju cijepljenje, ono ostaje samo na deklaratornoj razini i to ponajviše zbog praktičnih razloga zbog nedostatka vremena da se svakom pacijentu pojedinačno daju objašnjenja postupka i rizika. ${ }^{21}$ Osim toga, čak ako i dobije sve informacije o cijepljenju, u nekim je državama, primjerice u Republici Hrvatskoj, cijepljenje protiv određenih bolesti propisano zakonom $^{22}$ kao obvezatno, pa se onaj tko ga odbije suočava s novčanim kaznama.

17 Zakon o pravima pacijenata, Narodne novine, br. 37/08.

18 Kodeks medicinske etike i deontologije, Narodne novine, br. 55/08.

19 Field, R. I., Caplan, A. L., A Proposed Ethical Framework for Vaccine Mandates: Competing Values and the Case of HPV, Kennedy Institute of Ethics Journal, vol. 18, br. 2, 2008., str. 111-124, str. 113.

20 Op. cit. (Legal dictionary) u bilj. 13.

21 Davis, T. C., Fredrickson, D. D., Arnold, C. L., Cross, J. T., Humiston, S. G., Kristen Green, K. W., Bocchini, J. A., Childhood Vaccine Risk/Benefit Communication in Private Practice Office Settings: A National Survey, Pediatrics, vol. 107., br. 2., 2001., str. 1-11.

22 Zakon o zaštiti pučanstva od zaraznih bolesti, Narodne novine, br. 79/07., 113/08., 43/09., članak 40.: Imunizacija je obvezna: 1. protiv tuberkuloze, difterije, tetanusa, hripavca, dječje paralize, ospica, crvenke, zaušnjaka i virusne žutice tipa B i bolesti uzrokovanih s Haemophilus influenzae tip B - za sve osobe određene dobi, 2. protiv tetanusa ozlijeđenih osoba, 3. protiv virusne žutice tipa B - za osobe pod povećanim rizikom od zaraze, 4. protiv bjesnoće - za sve osobe koje su profesionalno izložene riziku od zaraze i koje ozlijedi bijesna životinja ili životinja za koju se sumnja da je bijesna, 5. protiv žute groznice - za osobe koje putuju u državu u kojoj postoji ta bolest ili u državu koja zahtijeva imunizaciju protiv te bolesti, 6 . protiv kolere i drugih zaraznih bolesti - za osobe koje putuju u državu koja zahtijeva imunizaciju protiv tih bolesti ili u slučajevima kada za to postoji epidemiološka indikacija, 7. protiv trbušnog tifusa i drugih zaraznih bolesti za sve osobe za koje postoje epidemiološke indikacije. 
O ustavnosti obveze cijepljenja odlučivao je i Ustavni sud Republike Hrvatske ${ }^{23} \mathrm{u}$ povodu prijedloga za pokretanje postupka za ocjenu suglasnosti Zakona o zaštiti pučanstva od zaraznih bolesti. ${ }^{24}$

U ovom ustavnosudskom postupku Ustavni sud trebao je odgovoriti na osnovno pitanje: Jesu li predviđene zakonske mjere u ostvarivanju zdravstvene zaštite ustavnopravno prihvatljive odnosno imaju li one legitimni cilj u općem interesu? Predlagatelji su se, između ostalog, pozivali na praksu Belgije, Francuske, Italije, Luksemburga, Njemačke, Velike Britanije, Nizozemske i Španjolske u fakultativnom odabiru cjepiva. ${ }^{25}$ Smatraju da je članak 40 . Zakona o zaštiti pučanstva od zaraznih bolesti, kojim se propisuje obveza cijepljenja protiv određenih zaraznih bolesti, u nesuglasnosti s člancima 35. i 64. (u dijelu koji se odnosi na pravo i slobodu samostalnog odlučivanja o odgoju djece) Ustava. Smatraju, također, da postoji nesuglasnost i s člancima 8. i 14. Konvencije za zaštitu ljudskih prava i temeljnih sloboda, koji govore o pravu na poštovanje privatnog i obiteljskog života i zabrani diskriminacije. $^{26}$

Ustavni sud odbio je prijedlog uz obrazloženje da je sa stajališta navedenih ustavnih odredbi, nedvojbena ovlast zakonodavca da zakonom propiše mjere zdravstvene zaštite, za koje je prema pravilima struke utvrđeno da postižu najpovoljnije rezultate u sprječavanju širenja zaraznih bolesti, kao i sankcije za one koji čine prekršaj, ne pridržavajući se propisanih mjera. Također smatra i da predlagatelji neutemeljeno navode kako je ustavno pravo roditelja da odluče hoće li imunizirati djecu. Imajući u vidu da Ustav roditeljskoj odgovornosti daje posebnu važnost i putem propisivanja roditeljskog prava i slobode da samostalno odlučuju o odgoju, Ustavni sud smatra da se zakonska obveza imunizacije radi sprječavanja zaraznih bolesti zbog zaštite zdravlja te zaštite prava drugih, ne može podvesti pod članak 64. Ustava. ${ }^{27}$ Nadalje, iznosi stajalište da je propisivanje cijepljenja usmjereno na eliminaciju bolesti iz ukupne populacije, što je pozitivna obveza države, koju zakonodavac želi ostvariti propisivanjem sveopće obveze pristupanja cijepljenju protiv određenih zaraznih bolesti. Smatra i da takav pristup zakonodavca ulazi u područje njegove slobodne procjene i da ne izlazi izvan ustavnih okvira. ${ }^{28}$

Očito je da se u državama koje propisuju obvezatno cijepljenje prisila na preventivni medicinski postupak opravdava ponajprije zaštitom javnih interesa. ${ }^{29}$

23 Rješenje Ustavnog suda Republike Hrvatske br.: U-I-5418/2008 od 30. siječnja 2014.

24 Zakon o zaštiti pučanstva od zaraznih bolesti, Narodne novine, br. 79/07., 113/08., 43/09.

25 Ibid. (Rješenje Ustavnog suda Republike Hrvatske) u bilj. 23.

26 Ibid.

27 Ibid.

28 Ibid.

29 Više v.: Hendrix, K. S., Lynne A. Sturm, L. A., Gregory D. Zimet, G. D., Meslin, E. M., Ethics and Childhood Vaccination Policy in the United States, Am. J. Public Health, vol. 106., br. 2., 2016., str. 273.-278.; Odluka Ustavnog suda Republike Slovenije, U-I-127/01, Uradni list RS 25/2004., dostupno na: https://www.uradni-list.si/glasilo-uradni-list-rs/vsebina/2004-01-1089/ odlocba-o-ugotovitvi-da-prva-alineja-prvega-odstavka-22--clena-4--tocka-prvega-odstavka57--clena-in-drugi-odstavek-57--clena-zakona-o-nalezljivih-boleznih-niso-v-neskladju-zustavo-in-o-ugotovitvi-neskladnosti-zakona-o-nalezljivih-boleznih-z-ustavo; pristupljeno: 25. studenog 2017. 
Međutim, iskustva zemalja koje ne propisuju prisilno cijepljenje govore da se može postići čak i veća procijepljenost i drugim, neprisilnim metodama. ${ }^{30}$

Možemo stoga zaključiti da u Republici Hrvatskoj pacijent ima pravo biti informiran o dobrobitima cijepljenja, kao i o rizicima od nuspojava, ali nema pravo na temelju tih informacija izabrati hoće li prihvatiti taj preventivni medicinski postupak, a ako štetni događaj nastupi, jedino mu preostaje uhvatiti se u koštac s pravosudnim sustavom te mukotrpnim i skupim postupcima dokazivanja.

\section{PROBLEMI MEDICINSKIH SUDSKIH SPOROVA}

Broj tužbi zbog štetnih posljedica cijepljenja posljednjih se godina sve više povećava. U nizu od tih presuda diljem svijeta dokazana je uzročno-posljedična veza između primljenog cjepiva i određenih bolesti te je izrečena novčana naknada štete zbog teškog oboljenja i invaliditeta te smrti zbog nuspojava cijepljenja. Tako je, primjerice, presudom Vrhovnog suda Republike Hrvatske (dalje: VSRH) od 10. lipnja 2009. utvrđena povezanost između dječje paralize i cjepiva protiv te bolesti. ${ }^{31}$

Sudski su postupci i inače teški i dugotrajni, ali u medicinskim su sporovima, zbog povreda po zdravlje ili život bliskih osoba iznimno emocionalno i financijski iscrpljujući. Osim toga, samo označavanje pasivno legitimirane osobe u tim je predmetima često zbunjujuće i nejasno je treba li tužiti liječnika, ustanovu (npr. dom zdravlja), državu, proizvođača cjepiva ili sve navedene. ${ }^{32} \mathrm{U}$ ovim je postupcima često i sporno odgovaraju li tuženici za naknadu štete tužiteljima na temelju krivnje ili po kriteriju uzročnosti. ${ }^{33}$

Naime, sukladno Zakonu o obveznim odnosima, ${ }^{34}$ odgovornost po kriteriju uzročnosti postojala bi u smislu definiranja postupka cijepljenja kao opasne djelatnosti te time odgovornost postoji i u slučaju slučajnih komplikacija cijepljenja. ${ }^{35}$ Tako, primjerice, i VSRH u presudi od 22. ožujka 2006. godine nalazi da će Republika Hrvatska odgovarati prema kriteriju uzročnosti bez obzira na to je li cijepljenje

30 Više v. Salmon, D. A., Teret, S. P., MacIntyre, C. R., Salisbury, D., Burgess, M. A., Halsey, N. A., Compulsory Vaccination and Conscientious or Philosophical Exemptions: Past, Present and Future, Lancet, 2006., str. 367., dostupno na: https://www.r esearchgate.net/ publication/7315037_Compulsory_vaccination_and_conscientious_or_philosophical_ exemptions_Past_present_an d_future, pristupljeno 23. listopada 2017.; Salmon, D. A., Mandatory Immunization Laws and the Role of Medical, Religious and Philosophical Exemptions, dostupno na: http://www.vaccinesafety.edu/exemptreview101503.pdf, pristupljeno: 23. listopada 2017.; Tucak, I., Obvezno cijepljenje djece: za i protiv, u: Rešetar, B., Aras Kramar, S., Lucić, N., Medić, I., Šago, D., Tucak, I., Mioč, P., Suvremeno obiteljsko pravo i postupak, Pravni fakultet u Osijeku, Osijek, 2017., str. 137.-165.

31 Presuda Vrhovnog suda Republike Hrvatske br. Rev 79/07-2 od 10. lipnja 2009. godine. Primjeri nekoliko stranih i domaćih presuda dostupni su na: http://www.cijepljenje.info/pravnikutak/presude/, pristupljeno: 15. studenog 2017.

32 Vidi primjerice $i b i d$.

33 Ibid.

34 Zakon o obveznim odnosima, Narodne novine, br. 35/05., 41/08., 125/11., 78/15.- dalje: ZOO).

35 Vidi primjerice op. cit. (Presuda Vrhovnog suda Republike Hrvatske) u bilj. 31. 
obavljeno stručno i pod nadzorom liječnika ili nije, jer je cijepljenje opasna djelatnost. ${ }^{36}$

Osim toga, hoće li se dokazivanju pristupiti temeljem kriterija krivnje ili uzročnosti bitno je raščlaniti i problem ispravnosti primljenog cjepiva. Ako je nuspojavu uzrokovalo ispravno cjepivo, bit će potrebno utvrditi postojanje krivnje tuženika prema općim pravilima o odgovornosti. Međutim, ako se utvrdi da cjepivo koje je izazvalo nuspojavu nije bilo ispravno, tada bi se primjenjivala pravila o odgovornosti zbog neispravnog proizvoda ${ }^{37}$ te će odgovornost postojati bez obzira na krivnju (arg. ex. čl. 1073. ZOO-a). U tom će slučaju, sukladno članku 1073/8. ZOO-a, oštećenik biti dužan dokazati neispravnost proizvoda, štetu i uzročnu vezu između neispravnosti proizvoda i štete.

Prema kriteriju krivnje, odgovornost postoji ako je došlo do propuštanja dužne pažnje, primjerice, ako liječnik ne provjeri zdravstveno stanje djeteta prije cijepljenja ili sukladno Zakonu o lijekova ${ }^{38}$ ne utvrdi je li cjepivo prošlo nužno ispitivanje prije stavljanja u promet. ${ }^{39}$

Međutim, kada je u pitanju odgovornost države, za potrebe rada, posebno je važno utvrđenje VSRH-a u presudi od 10. lipnja 2009. godine, u kojoj iznosi stajalište o odgovornosti Republike Hrvatske po kriteriju uzročnosti i to ne samo temeljem toga što je cijepljenje opasna djelatnost, nego i time što je cijepljenje obavezatno. Naime, VSRH iznosi da je Republika Hrvatska Zakonom o zaštiti pučanstva od zaraznih bolesti propisala obvezatno cijepljenje između ostalog i protiv dječje paralize. Prema mišljenju toga Suda, radi se o nužnoj i korisnoj mjeri, kojom su se sve osobe obuhvaćene Programom te javnozdravstvene zaštite dužne podvrći. ${ }^{40} \mathrm{U}$ skladu s time su postupili i roditelji tužitelji kada su svoje dijete doveli na cijepljenje čime su ispunjavali svoju zakonsku obvezu. Međutim, u ovom je konkretnom slučaju došlo do komplikacija, jer je nakon primanja cjepiva protiv dječje paralize maloljetnik obolio od te bolesti $i$ to unatoč činjenici da se radi o ispravnom cjepivu te je liječnica postupala s dužnom pažnjom. ${ }^{41}$

Nadalje, da bi se uspjela dokazati uzročna veza između cijepljenja i štetne nuspojave potreban je angažman velikoga broja medicinskih stručnjaka vještaka. Dokazivanje će biti iznimno teško i zbog toga što u znanstvenoj literaturi postoji i niz oprečnih stajališta o štetnosti cijepljenja. Stoga sudovi uglavnom u dosadašnjoj praksi najčešće nisu prihvaćali mogućnost da cjepiva mogu imati neželjene nuspojave, jer su medicinski stručnjaci u pravilu tvrdili da nema konkretnih medicinskih znanstvenih dokaza koji potvrđuju da cjepiva nanose štetu. Primjerice, takvo shvaćanje proizlazi i iz presude francuskoga Žalbenog suda u Parizu od 7. ožujka 2014. godine, koji je, odlučujući nakon što mu je predmet vraćen u povodu kasacijske žalbe, utvrdio

36 Presuda Vrhovnog suda Republike Hrvatske br. Rev 785/05-2 od 22. ožujka 2006. godine.

37 Proizvod nije ispravan ako, uzimajući u obzir sve okolnosti slučaja, a poglavito način na koji je proizvod predstavljen, svrhe u koje, prema razumnom očekivanju, proizvod može biti uporabljen te vrijeme kad je proizvod stavljen u promet, ne pruža sigurnost koja se od takva proizvoda opravdano očekuje (čl. 1075/1. ZOO-a).

38 Zakon o lijekovima, Narodne novine, br. 76/13., 90/14.

39 Vidi primjerice op. cit. (Presuda Vrhovnog suda Republike Hrvatske) u bilj. 31.

40 Ibid.

41 Ibid. 
da ne postoji znanstveni konsenzus o tomu da između cjepiva protiv hepatitisa B i nastanka multiple skleroze postoji uzročna veza i da su sva nacionalna i međunarodna zdravstvena tijela odbila vezati vjerojatnost pojave te bolesti uz cjepivo. ${ }^{42}$

Ipak, olakšavanju dokazivanja mogla bi uvelike pridonijeti nedavna presuda Suda Europske unije prema kojoj nacionalni sudovi mogu, razmatrati mogućnost da je cijepljenje dovelo do razvoja neke bolesti ili oštećenja, čak i onda kada za to ne postoji medicinski dokaz.$^{43}$ Presuda je donesena povodom zahtjeva za prethodnu odluku koja se odnosi na tumačenje članka 4. Direktive Vijeća 85/374/EEZ od 25. srpnja 1985. o približavanju zakona i drugih propisa država članica u vezi s odgovornošću za neispravne proizvode ${ }^{44}$ na temelju članka 267. UFEUa, koji je uputio Cour de cassation (Francuska). Sukladno ovoj presudi, unatoč nepostojanju znanstvenog konsenzusa, cjepivo se može smatrati neispravnim, ako postoje specifični i konzistentni dokazi, uključujući vrijeme između primanja cjepiva, prethodnoga zdravstvenog stanja oštećenika, obiteljske anamneze te velikog broja prijavljenih slučajeva iste bolesti koja se pojavila nakon cijepljenja. ${ }^{45}$

\section{ALTERNATIVNO RJES̆AVANJE MEDICINSKIH SPOROVA}

Alternativno rješavanje sporova način je rješavanja sporova različit u odnosu na parnični postupak, koji se uveo u pravosudnu praksu, ne da bi zamijenio postupak pred sudom, nego radi ponude većeg broja mogućnosti učinkovitijeg i kvalitetnijega sustava rješavanja sporova.$^{46}$ Alternativno rješavanje sporova obuhvaća sve izvansudske načine rješavanja sporova, bez obzira na posebnosti u njihovim metodama rješavanja sporova. Osnovni cilj ovog načina rješavanja sporova, rješavanje je zategnutih odnosa u što ranijoj fazi uz što manje troškova. Alternativno rješavanje sporova daje nam, dakle dodatnu mogućnost opredjeljenja za nove načine rješavanja sporova. ${ }^{47}$

Korisno bi bilo stoga prepoznati kako rješavanje medicinskih sporova korištenjem izvansudskih alternativnih metoda ukazuje na niz prednosti. Međutim, uočljiv je i niz karakteristika zdravstva koje ga čine manje podobnim za takav način rješavanja sporova. ${ }^{48}$

Naime, karakteristika zdravstva, kao društvenog sustava, široka je nejednakost moći, znanja i kontrole. Kompleksna priroda zdravstvenog sustava čini ga time težim za razumijevanje i za njegove sudionike, tako i za osobe koje bi trebale rješavati sukobe

42 Iz presude Suda Europske unije C621/15, W and Others v. Sanofi Pasteur MSD SNC, 21 June 2017., t. 16.

43 Ibid.

44 Direktiva Vijeća 85/374/EEZ od 25. srpnja 1985. o približavanju zakona i drugih propisa država članica u vezi s odgovornošću za neispravne proizvode (SL 1985., L 210, str. 29.).

45 Op. cit. (presuda Suda Europske unije) u bilj. 42.

46 Bilić, V., Alternativno rješavanje sporova i parnični postupak, doktorska disertacija, Zagreb, 2008., str. 9.

47 Ibid.

48 Knol Radoja, K., Alternativno rješavanje medicinskih sporova, u: Mićović, M. (ur.), Zbornik XII. Međunarodnog majskog savjetovanja "Usluge i uslužna pravila", Kragujevac, 2016., str. 589-608, str. 600 . 
unutar njega. Zdravstveni sustav raspolaže nizom podataka od životne važnosti, a opet, u praksi, često s ograničenim pristupom tim informacijama. Nejednakosti se ponajprije očituju između pružatelja zdravstvenih usluga i pacijenata, ali također su prisutne i među skupinama pružatelja usluga (liječnici, medicinske sestre i drugi), vrste usluga (primarne zdravstvene zaštite $\mathrm{u}$ odnosu na specijalističku skrb ili kurativnog $\mathrm{u}$ odnosu na preventivno djelovanje) i slično. ${ }^{49}$

Još jedna značajka zdravstva znatna su odstupanja u vrijednosnim sustavima različitih profesionalnih i neprofesionalnih grupa koje se nađu u sustavu. Pacijenti i njihove obitelji će na neki zdravstveni problem gledati često drukčije nego liječnici. Problemi koji se pojave u pružanju zdravstvene usluge, bilo kurativne, bilo preventivne, drukčije će promatrati liječnici, socijalni radnici, farmaceuti ili pravnici, što njegovo rješavanje čini iznimno kompleksnim zbog potrebe za pomirenjem tih različitih poimanja vrijednosti. ${ }^{50}$ Kako bi se te nejednakosti pomirile treba biti iznimno oprezan u izboru stručnih osoba zaduženih za rješavanje ovih vrsta sporova te oformiti tijelo koje može objektivno sagledati štetni događaj iz svih perspektiva, a ne samo pogodujući jednoj strani.

Sudski postupci u medicinskim sporovima često su dugi, iscrpljujući i skupi. Neučinkovitost, odnosno kašnjenje u odnosu na optimalno ili čak krajnje vrijeme potrebno za rješavanje pojedinog spora sve je izraženiji problem pravosuđa. Poticanje alternativnih načina rješavanja sporova doprinosi ostvarenju prava na pravično suđenje u razumnom roku zajamčeno Ustavom Republike Hrvatske ${ }^{51}$ (članak 27.) i Europskom konvencijom za zaštitu ljudskih prava i temeljnih sloboda ${ }^{52}$ (članak 6.). Korištenje alternativnih načina rješavanja sporova preuzimanjem dijela sudskog opterećenja doprinosi smanjenju sudskih zaostataka. Poticanje alternativnih načina rješavanja sporova često se stoga u političkim dokumentima, poput Strategije reforme pravosuđa, ${ }^{53}$ spominje kao metoda rješavanja problema učinkovitosti pravosuđa..$^{54}$

U Republici Hrvatskoj je već godinama poznat problem velike opterećenosti sudova. Iako se pred hrvatskim sudovima ne vodi veliki broj predmeta zbog naknade štete prouzročene cijepljenjem i kod njih se nailazi na problem kašnjenja i povrede prava na suđenje u razumnom roku. Zbog toga, potencijalno, osobe koje su teško povrijeđene, pa i do razine trajnog invaliditeta, ponekad moraju i godinama čekati na novčanu naknadu štete koja im je potrebna za liječenje, a sve zbog toga što su ispunili svoju zakonsku dužnost. Tako, primjerice, i VSRH u odluci od 21. prosinca 2009. godine predlagatelju određuje novčanu naknadu zbog povrede prava na suđenje u razumnom roku. U ovom je predmetu tužitelj 14. lipnja 2001. godine podnio tužbu radi isplate naknade štete zbog komplikacija nakon cijepljenja, a meritorna odluka

49 Ibid.; Morrison, G., Robson, R., ADR in Healthcare: The Last Big ADR Frontier?, dostupno na: http://www.mediate.com/articles/robmorr1.cfm, pristupljeno 3. ožujka 2016.

50 Knol Radoja, op. cit. u bilj. 48., str. 601.

51 Ustav Republike Hrvatske, Narodne novine, br. 56/90., 135/97., 113/00., 28/01., 76/10., 5/14.

52 Europska konvencija za zaštitu ljudskih prava i temeljnih sloboda, Narodne novine, Međunarodni ugovori, br. 18/97., 6/99., 14/02., 13/03., 9/05., 1/06., 2/10.

53 V. primjerice Strategija reforme pravosuđa za razdoblje od 2013. do 2018. godine, Narodne novine, br. 144/12.

54 Knol Radoja, op. cit. u bilj. 48., str. 593. 
žalbenog suda o predmetu spora dostavljena mu je tek 4 . kolovoza 2008. godine. ${ }^{55}$

Zbog svega navedenog, u nekim se državama u potpunosti napušta sustav deliktne odgovornosti u korist, tzv. no-fault sustava, kao jedne vrste alternativnog rješavanja sporova. ${ }^{56} \mathrm{U}$ državama koje su ga uvele, osobama koje su pretrpjele štetu zbog nuspojave cijepljenja, isplaćuje se unaprijed utvrđeni iznos naknade bez obzira na postojanje ili nepostojanje krivnje zdravstvenog djelatnika. Takvi se iznosi isplaćuju bez odlaganja. ${ }^{57}$

Ovi sustavi u pravilu ne dovode u pitanje pravo stranke da se, unatoč postojanju alternativnog puta, za svoja prava, ako to žele, izbore pred sudom. Ipak, obeštećenje putem izvansudskih programa naknade štete u nekim se državama, primjerice Sjedinjenim Američkim Državama, potiče na način da ga čak propisuje kao procesnu pretpostavku za podnošenje tužbe za naknadu štete sudu (v. infra).

Iako se propisivanje alternativnog načina rješavanja spora može činiti kao ograničavanje temeljnoga ljudskog prava na pristup sudu, znanost i praksa dale su suprotan odgovor. O pitanju ograničavanja prava na pristup sudu iz članka 6/1. Europske konvencije za zaštitu ljudskih prava i temeljnih sloboda ${ }^{58}$ bez prethodnog pokušaja izvansudskog mirenja raspravljalo se pred Europskim sudom za ljudska prava 2001. godine u predmetu Prince Hans-Adam II of Liechtenstein v. Germany. ${ }^{59} \mathrm{U}$ toj je presudi Europski sud za ljudska prava utvrdio kako se propisivanjem pokušaja sporazumnog rješenja spora prije podnošenja tužbe sudu ne krši konvencijsko pravo na pristup sudu. Sud je iznio stajalište da to pravo nije apsolutno pa ga države stoga mogu ograničiti u legitimnom cilju na način koji ne narušava njegovu bit, uz razborit omjer razmjernosti između ograničavajućega sredstva i propisanog cilja. ${ }^{60}$

Vezano uz alternativno rješavanje sporova, konkretno mirenja u Republici Hrvatskoj kada je ona stranka u sporu, sukladno odredbi 186. a Zakona o parničnom postupku $^{61}$ prije podnošenja tužbe, tužitelj bi se morao obratiti sa zahtjevom za mirno rješavanje spora stvarno i mjesno nadležnom državnom odvjetništvu. Obveza ne postoji jedino u slučaju kada je posebnim propisima određen rok za podnošenje tužbe te kada je posebnim zakonom propisan postupak podnošenja zahtjeva za mirno rješenje spora nadležnom državnom odvjetništvu ili nekom drugom tijelu. Dakle, de lege lata, ako je Republika Hrvatska tužena za naknadu štete prouzročene

55 Odluka VSRH br. Gzp 170/08-8 od 21. prosinca 2009. godine.

56 Danzon, P. M., The swedish patient compensation system: myths and realities, International Review of Law and Economics, vol. 14., 1994., str. 453-466; Davis, P., R. Lay-Yee, J. F. P. Hider, R. Briant, S. Schug, Compensation for Medical Injury in New Zealand: Does "No-Fault" Increase the Level of Claims Making and Reduce Social and Clinical Selectivity?, J. Health Polit Policy Law, vol. 27., 2002., str. 833-854.

57 Mariner, W. K., National Vaccine Injury Compensation Program, Health Affairs, vol. 11., br. 1., 1992., str. 255-265.

58 Europska konvencija za zaštitu ljudskih prava i temeljnih sloboda, Narodne novine, Međunarodni ugovori, br. 18/97., 6/99., 14/02., 13/03., 9/05., 1/06., 2/10.

59 Prince Hans-Adam II of Liechtenstein v. Germany, Application no. 42527/98, od 12. srpnja 2001. godine.

60 Ibid.

61 Zakon o parničnom postupku, Narodne novine, br. 53/91., 91/92., 112/99., 129/00., 88/01., 117/03., 88/05., 2/07., 96/08., 84/08., 123/08., 57/11., 25/13., 89/14. 
cijepljenjem, bit će nužno, prije podnošenja tužbe sudu, provođenje postupka mirenja pred državnim odvjetništvom. Navedena odredba iznimno je važna zbog poticanja stranaka na mirenje, što je u medicinskim sporovima posebno poželjno. Ipak, s obzirom na to da država nije jedina koja je potencijalni tuženik u postupcima naknade štete prouzročene cijepljenjem, de lege ferenda, bilo bi poželjno ugledati se na poredbene primjere drugih država koje predviđaju neki oblik mirenja kroz posebne programe pred za to oformljenim stručnim tijelom (vidi infra).

\section{PROGRAMI NAKNADE ŠTETE PROUZROČENE CIJEPLJENJEM (NO-FAULT COMPENSATION)}

U brojnoj se znanstvenoj literaturi iznose koristi koje donosi provedba tzv. imunizacije protiv uglavnom dječjih zaraznih bolesti. Međutim, sve se češće u javnosti upozorava i na niz teških i vrlo teških nuspojava cijepljenja. Iako je u većini slučajeva nemoguće unaprijed predvidjeti mogućnost javljanja štetne nuspojave cjepiva, u pravilu sve države propisuju ili preporučuju cijepljenje djece najkasnije do polaska u školu. Roditelji djece koja su teško ozlijeđena cjepivom imaju mali broj mogućnosti za borbu s ovom nasumičnom tragedijom koja se dogodila njihovoj obitelji.

Programi odštete rezultat su brojnih kontroverzi pravnog rješavanja problema nuspojava cijepljenja. Prije njihova zakonskog reguliranja, jedino čemu su roditelji djece oštećene cjepivom mogli pribjeći, bila je dugotrajna i skupa parnica. Građanske parnice često su dugotrajne i skupe, a uzročno-posljedične veze između ozljede i cjepiva teško dokazive. $\mathrm{S}$ druge strane, ako tužitelj uspije sa svojim zahtjevom, dosuđeni iznosi mogu biti znatno veći od onih utvrđenih programom te zbog publiciteta jače utjecati na negativno mišljenje javnosti o sigurnosti cjepiva. Ideja je programa smanjiti troškove i nesigurnost parnice te osigurati pravednu naknadu osobama ozlijeđenim ovim medicinskim postupkom.

U deliktnom pravu određivanje naknade štete temelji se na utvrđivanju krivnje u svakom pojedinačnom slučaju, pa je stoga, bez dokaza postojanja, u najmanju ruku, nepažnje u provođenju određenoga medicinskog postupka, teško ostvariti naknadu štete putem uobičajenih zakonskih mehanizama. No-fault sustav razlikuje se po tomu što se u njemu kompenziraju sve povrede bez obzira na krivnju. Na prvi pogled, moglo bi se činiti da bi takav sustav doveo do povećanja troškova, međutim, njegovi zagovornici iznose da su njegove osnovne prednosti, kao alternativnog postupka, upravo smanjenje troškova koji se ponajprije odnose na plaćanje odvjetnicima, a također i ubrzanje postupka zbog izbjegavanja spora i skraćivanje vremena potrebnog za rješavanje zahtjeva u odnosu na parnični postupak. ${ }^{62}$ Umjesto trošenja mjeseci pa i godina te troškova za odvjetnike i vještačenja za utvrđivanje krivnje, u nofault sustavima naknade za određene ozljede utvrđene su unaprijed pa se time i do kompenzacije dolazi puno brže i bez odugovlačenja. ${ }^{63}$

62 Plotkin, S. A., Lessons learned concerning vaccine safety, Vaccine, vol. 20., suppl. 1., 2001., str. 16-19.

63 Weiler, P. C., Hiatt, H. H., Newhouse J. P., et al., A Measure of malpractice: medical injury, malpractice litigation, and patient compensation, Cambridge, Mass., Harvard University 
Mogućnost nadoknade štete povrijeđenima kada nema krivnje u literaturi je označena čak pravednijom. ${ }^{64}$ Osim toga, i podnositelji zahtjeva pokazali su zadovoljstvo što su primili naknadu putem ovakvog pojednostavljenog postupka ${ }^{65}$ Kao izvansudski alternativni način rješavanja sporova, programi naknade štete zbog nuspojava cijepljenja brži su, fleksibilniji i jednostavniji od parničnog postupka i time znatno pristupačniji pojedincima.

Povjerenje javnosti u imunizaciju sve je važnije globalno zdravstveno pitanje. Gubitak povjerenja u cjepiva i programe imunizacije mogu dovesti do usporavanja procesa primanja i odbijanja cjepiva, a time i potencijalnog rizika od epidemija bolesti. Stoga posljednjih godina međunarodni akteri imunizacije sve češće pozivaju na bolji nadzor povjerenja u cjepiva te prepoznavanje problema prije nego što evoluiraju $\mathrm{u}$ krize povjerenja u cijepljenje. ${ }^{66}$ Pritom je nepreuzimanje odgovornosti za nastupjelu štetu zbog cijepljenja jedan od važnijih uzroka pojave opadanja povjerenja građana u postupak imunizacije, posebice kada je ona obvezatna. Budući da je država ta koja $\mathrm{u}$ javnom interesu, ponekad i pod prisilom, propisuje cijepljenje, ona je ta koja bi putem nacionalnih programa za obeštećenje trebala osigurati oštećenim pojedincima naknadu štete. Obrazovanje stanovništva o opasnostima od zaraznih bolesti zajedno s prihvaćanjem programa naknade potiče povjerenje javnosti. Naime, učinkovitost politike cijepljenja ne ovisi izravno o postojanju povjerenja cijepljenih osoba, ali povjerenje može biti ključno za spremnost pojedinca na cijepljenje ili za cijepljenje njegovog djeteta. ${ }^{67}$

Prepoznavši navedene prednosti, nekoliko je država implementiralo programe naknade štete prouzročene cijepljenjem (vaccine-injury compensation programmes). ${ }^{68}$ Prva među njima bila je Njemačka, ${ }^{69}$ koja je taj program uvela još 1961. godine.

Press., 1993.

64 Mehlman, M. J., Resolving the medical malpractice crisis: Fairness considerations, Faculty Publications, 2003., str. 75.

65 Balinska, M. A., Vaccination in tomorrow's society, Lancet Infect Diseases, vol. 3., br. 7., 2003., str. 443-447.

66 Larson, H. J., Figueiredo, A., Xiahong, Z., Schulz, W. S., Verger, P., Johnston, I. G., Cook, A. R., Jones, N. S., The State of Vaccine Confidence 2016: Global Insights Through a 67-Country Survey, EBioMedicine, vol. 12., 2016., str. 295-301., dostupno na: https://www.ncbi.nlm.nih. gov/pmc/articles/PMC5078590/, pristupljeno: 20. veljače 2018.

67 Parmet, W. E., Informed Consent and Public Health: Are They Compatible When it Comes to Vaccines?, Journal of Health Care Law \& Policy, vol. 8., br. 1., 2005., str. 71-110., str. 97.

68 Više v. Looker, C., Kelly, op. cit. u bilj. 6.

69 Protection against infection act (Infektionsschutzgesetz - IfSG), 1045; 20 July 2000. Berlin: Federal Law Gazette; 2000., dostupno na: http://www.rki.de/cln_162/nn_217358/EN/Content/ Prevention/Inf_Dis_Surveilla nce/inf_dis_down.html?_nnn=true, pristupljeno: 30. rujna 2017. 
Osim u Njemačkoj, slični programi postoje u Francuskoj, ${ }^{70}$ Austriji ${ }^{71}$ Danskoj, ${ }^{72}$ Švedskoj, ${ }^{73}$ Švicarskoj, ${ }^{74}$ Velikoj Britaniji, ${ }^{75}$ Sjevernoj Irskoj, Finskoj, ${ }^{76}$ Novom Zelandu, ${ }^{77}$ Japanu, ${ }^{78}$ Kini, Sjedinjenim Američkim Državama, ${ }^{79}$ Kanadi (Quebec) ${ }^{80}$

70 Dispositif de règlement amiable des dommages imputables à des vaccinations obligatoires (in French). Paris: Office National d'Indemnisation des Accidents Médicaux; 2004., dostupno na: http://www.oniam.fr/vaccinations.php, pristupljeno: 30. rujna 2017.

71 Act for the compensation of vaccination damages (Impfschadengesetz, BGBI nr. 371/1973) (in German). Vienna: Bundeskanzleramt; 1973., dostupno na: http://www.ris.bka.gv.at/Ergebnis. wxe? Suchworte $=371 \% 2 F 1973 \& \mathrm{x}=0 \& \mathrm{y}=0 \& \mathrm{Abfra}$ ge $=$ Gesamtabfrage, pristupljeno: 30 . rujna 2017.

72 The Danish Liability for Damages Act. Copenhagen: Patientforsikringen; 2010., dostupno na: http://www.patientforsikringen.dk/en/Love-og-Regler/Lov-omklage-og-erstatningsadgang/ Behandlingsskader.aspx, pristupljeno: 30. rujna 2017.

73 The Undertaking (Indemnity rules). Stockholm: Lakemedelsforsakringen(LFF);2009., dostupno na: http://www.lakemedelsforsakringen.se/default.asp?id=10822\&ptid=, pristupljeno: 11 . rujna 2017.

74 Federal law from 18 December 1970 on communicable disease control (Epidemics act) 818.101. Berne: Federal Authorities of the Swiss Confederation;1970. dostupno na: http:/www.admin. $\mathrm{ch} / \mathrm{ch} / \mathrm{d} / \mathrm{sr} / \mathrm{c} 818 \_101 . \mathrm{html}$, pristupljeno: 11. rujna 2017.

75 The Regulatory Reform (Vaccine Damage Payments Act 1979) Order 2002, Statutory Instrument 2002 no. 1592. London: Office of Public Sector Information; 2002., dostupno na: http://www.opsi.gov.uk/si/si2002/20021592.htm, pristupljeno: 11. rujna 2017.

76 Finnish Pharmaceutical Insurance Pool [Internet site]. Helsinki: Finnish Pharmaceutical Insurance Pool; 2011., dostupno na: http://www.lvp.fi/www/page/lvp_www_2090, pristupljeno: 11. rujna 2017.

77 Accident Compensation Act 1972, s. $2 \S$ amended by Accident Compensation Amendment Act 2001. Wellington: New Zealand Legislation; 2001., dostupno na: http://www.legislation.govt. nz, pristupljeno: 11. rujna 2017.

78 Cabinet order no. 197 on implementation of immunization law, Tokyo, 1948., dostupno na: http://hourei.ndl.go.jp, pristupljeno: 30. rujna 2017.; v.: Hiroki Nakatani, Tadashi Sano, Tsutomu Iuchi, Review. Development of Vaccination Policy in Japan: Current Issues and Policy Directions, Jpn. J. Infect. Dis., vol. 55., 2002., str. 101.-111.

79 National Childhood Vaccine Injury Act. 1986, dostupno na: http://www.hrsa.gov/ vaccinecompensation/authorizinglegislation.pdf, pristupljeno: 30. rujna 2017.

80 Public Health Protection Act, RSQ, chapter S-2.2., dostupno na: http://legisquebec.gouv.qc.ca/ en/ShowDoc/cs/S-2.2, pristupljeno: 11. rujna 2017. 
Italiji, ${ }^{81}$ Norveškoj, ${ }^{82}$ Koreji, ${ }^{83}$ a od nedavno i u Mađarskoj, ${ }^{84}$ Islandu $^{85}$ i Sloveniji ${ }^{86}$

U nastavku će biti nekoliko riječi o navedenim programima u Sjedinjenim Američkim Državama, budući da je tamo ovaj alternativni sustav naknade iznimno razvijen, te u Sloveniji, kao primjeru susjedne države koja je također prihvatila ovaj način obeštećenja kao bržeg i učinkovitijeg. U Republici Hrvatskoj nisu oformljeni programi izvansudske naknade štete zbog nuspojava cijepljenja ni djece, koja su najčešće oštećena, ni odraslih, ali je već godinama potvrđeno pravo na naknadu, ako zbog cijepljenja nastane šteta posjedniku domaće životinje (v. infra).

\subsection{Sjedinjene Američke Drăave}

Posebno izražen problem izazvan velikim brojem odštetnih zahtjeva nastao je od 1980. do 1984. godine u Sjedinjenim Američkim Državama kada su potraživanja naknade štete zbog nuspojava cijepljenja iznosila preko 3,5 milijardi dolara i time izazvala napuštanje tržišta šest od osam proizvođača cjepiva. Mnogi od tih proizvođača tvrdili su da je tomu razlog nepostojanje osiguranja od odgovornosti zbog proizvoda. ${ }^{87}$ Napuštanje tržišta velikog broja proizvođača izazvalo je nagli pad u proizvodnji i dovelo u pitanje opskrbu dostatnom količinom cjepiva. ${ }^{88}$

Kako bi se smanjio pritisak, godine 1986. uveden je savezni Program naknade štete zbog nuspojava cijepljenja (National Vaccine Injury Compensation Program, dalje: VICP). VICP se temelji na no-fault sustavu i funkcionira kao alternativa tradicionalnom građanskom postupku za naknadu štete. Naknada se određuje sukladno tablici (Vaccine Injury Table) u kojoj se nalazi lista mogućih povreda i vremenski okviri u kojima se moraju pojaviti kako bi se kvalificirale kao nuspojave. Temeljem VICP-a naknadu mogu ostvariti povrijeđeni pojedinci, odnosno njihovi zakonski zastupnici koji su pretrpjeli štetu od nekog u tablici taksativno navedenog

81 Law no. 238 of 25 July 1997, modifications and additions to the Law no. 210 of February 25 1992 , relating to compensation to those harmed by mandatory vaccinations, blood transfusions and blood products (in Italian). Rome: Ministry of Health; 1997., dostupno na: http://www. normattiva.it, pristupljeno: 11. rujna 2017.

82 Patient Injury Act of 15 June 2001 no. 53 (in Norwegian). Oslo: Ministry of Health; 2001., dostupno na: http://www.lovdata.no/all/nl-20010615-053.html, pristupljeno: 11. rujna 2017.

83 Prevention of Contagious Diseases Act, Law 6162 (in Korean). Seoul: Korean Centers for Disease Control and Prevention; 2009., dostupno na: http://www.glin.gov/view.action?glinID=70100, pristupljeno: 11. rujna 2017.

84 Hungarian Health Code (1997. CLIV), dostupno na: https://www.lexadin.nl/wlg/legis/nofr/ eur/lxwehun.htm\#Health\%20Law, pristupljeno: 11. rujna 2017.

85 Act on patient insurance no. 111/2000. Reykjavik: Ministry of Welfare; 2000., dostupno na: http://eng.velferdarraduneyti.is/acts-of-Parliament/nr/20366, pristupljeno: 11. rujna 2017.; v.: Boncz I, Sebestyen A., Compensation for vaccine injury in Hungary, Lancet vol. 367., 2006., str. 1144.

86 Looker, C., Kelly Op. cit. u bilj. 6.

87 Sloan, F. A., The Economics of Vaccines, u: Danzon, P. M., Sean Nicholson, S.,The Oxford Handbook of the Economics of the Biopharmaceutical Industry, Oxford University Press, New York, 2012., str. 544.

88 Više v. Evans G., Levine E. M., Saindon E. H., Legal issues, u: Plotkin S. A., Orenstein W. A., Offit P. A., Vaccines, Saunders Elsevier, Philadelphia, 2008. 
cjepiva ${ }^{89} \mathrm{u}$ određenom prekluzivnom roku. ${ }^{90}$ Ako se tužitelj u zahtjevu poziva na neku od nuspojava navedenu u tablici, tada pretpostavka uzročnosti ide u njegovu korist pa se teret dokazivanja prebacuje na Vladu, koja će morati dokazati da je ozljeda prouzrokovana drugim specifičnim čimbenikom koji nije povezan s cjepivom. Ako se ozljeda ne nalazi u tablici, tužitelj će morati dokazati da je cjepivo doista prouzrokovalo ozljedu bez ikakve pretpostavke uzročnosti u njegovu korist. ${ }^{91}$

Budući da je VICP alternativni izvor naknade, podnositelji zahtjeva zadržavaju pravo na podnošenje tužbe. Međutim, podnositelji zahtjeva tu tužbu ne mogu podnijeti dok ne podnesu zahtjev u skladu s VICP-om, dobiju konačnu odluku i u korist parnice odluče ju ne prihvatiti. ${ }^{92}$ Tužba se, također, može podnijeti i ako će zahtjev biti odbijen, a budući da se naknada temeljem VICP-a može ostvariti samo za taksativno navedena cjepiva, tužba se može podnijeti i ako primljeno cjepivo nije obuhvaćeno VICP-om. ${ }^{93}$ Osim toga, ako se odluka ne donese u roku od 240 dana, odnosno, ako je uložena žalba, u roku od 420 dana, podnositelj ima pravo taj zahtjev povući te tužbu izravno podnijeti građanskom sudu. ${ }^{94} \mathrm{U}$ ostalim će slučajevima nepodnošenje zahtjeva predstavljati negativnu procesnu pretpostavku za pokretanje građanske parnice. ${ }^{95}$

\subsection{Slovenija}

Ustavni sud Republike Slovenije proglasio je 2004. godine Zakon protiv zaraznih bolesti neustavnim jer ne regulira prava zainteresiranih osoba i postupak utvrđivanja postojanja opravdanih razloga za odustajanje od obveznog cijepljenja, kao i zbog neadekvatnog uređenja odgovornosti za štetu zbog nuspojava cijepljenja. Stoga je naložio Parlamentu ispravljanje navedenih nedostatka u roku od godine dana od objave odluke u Službenom glasilu Republike Slovenije. ${ }^{96}$

U obrazloženju svoje presude, Sud je iznio stajalište kako je obvezno cijepljenje, iako zadire u temeljna ljudska prava, opravdano u svrhu zaštite opće populacije i ako udovoljava općem načelu proporcionalnosti, odnosno prikladna je mjera za postizanje legitimnog cilja - prevencije i kontrole zaraznih bolesti. Međutim, ono što je za potrebe ovog rada posebno važno, u obrazloženju se iznosi i da je, kao i kod bilo

89 Diphtheria, tetanus, pertussis (DTP, DTaP, DT, TT, or Td), measles, mumps, rubella (MMR or any components), polio (OPV or IPV), hepatitis B, Haemophilus influenzae type b (Hib), varicella (chicken pox), rotavirus and pneumococcal conjugate vaccines (National Vaccine Injury Compensation Program, t. 2., dostupno na: https://www.in.gov/isdh/files/VICP.pdf, pristupljeno 22. rujna 2017.

90 Prospective claims for injury must be filed within thirty-six months after manifestation of the injury. Prospective claims for death must be filed within twenty-four months after the date of death, but no later than forty-eight months after manifestationof the injury that resulted in death (42 U.S.C. 300aa-16(a)(2),(3).).

91 Keelan, Wilson $O p$. cit. u bilj. 7.

92 Mariner Op. cit. u bilj. 57., str. 257.

93 National Vaccine Injury Compensation Program, t. 12.

94 42 U.S.C.A. §300aa-21(b)., dostupno na: https://www.law.cornell.edu/uscode/text/42/300aa-21, pristupljeno 26. rujna 2017.

95 Mariner Op. cit. u bilj. 57., str. 257.

96 Odluka Ustavnog suda Republike Slovenije Op. cit. u bilj. 29. 
koje medicinske intervencije, cijepljenje povezano s određenim rizicima, pa je stoga zakonodavac dužan pružiti odgovarajući pravni lijek. Iznosi da su, u dosadašnjoj praksi na svaki zahtjev za odštetu u slučajevima kada je zbog obveznog cijepljenja nastupila šteta po zdravlje pojedinca, primjenjivana opća pravila o odgovornosti za štetu. Ustavni sud, međutim, smatra da bi zakonodavac trebao pojedinačno regulirati naknadu šteta. ${ }^{97}$ Načelo solidarnosti, koje je, između ostalog, i osnova za određivanje obvezne mjere cijepljenja, zahtijeva da država koja takvu mjeru nalaže u opću korist i kompenzira time povrijeđenu osobu. S obzirom na to, Sud smatra da je neprihvatljivo ako bi pojedinac trebao pretrpjeti štetu koja mu je prouzročena obveznom zdravstvenom mjerom koja je određena za javnu dobrobit. Zakonodavac je stoga obvezan izričito odrediti naknadu za takve slučajeve. ${ }^{98}$

Odgovornost za štetu nastalu zbog obveznog cijepljena regulirana je u Sloveniji Zakonom o zaraznim bolestima u člancima 53 a do 53 f. ${ }^{99}$ Prema navedenim odredbama, osoba koja je zbog cijepljenja pretrpjela štetu po zdravlje, a što se ogleda u ozbiljnom i trajnom gubitku životnih funkcija, ima pravo na naknadu. Ako osoba umre zbog posljedica obveznog cijepljenja, pravo na naknadu ${ }^{100}$ ima njihov bračni ili izvanbračni drug, djeca i roditelji. Navedene odredbe Zakona ne primjenjuju se na štetu uzrokovanu nepravilnom primjenom cjepiva ili zbog neadekvatne kakvoće cjepiva u skladu s propisima koji uređuju medicinske proizvode. Osim toga, opća pravila građanskopravne odgovornosti će se primjenjivati ako se šteta dogodila zbog nepravilnog ponašanja profesionalnih osoba u slučaju cijepljenja ili neodgovarajuće kvalitete cjepiva. Postupak za ostvarivanje prava na naknadu temeljem ovoga Zakona započinje podnošenjem zahtjeva ${ }^{101}$ Ministarstvu nadležnom za zdravstvo najkasnije $u$ roku od šest godina od datuma cijepljenja. O pravu na naknadu prema ovom Zakonu odlučuje ministar nadležan za zdravstvo na temelju stručnog mišljenja Komisije za utvrđivanje uzročne veze između obveznog cijepljenja i štete, sastavljene od stručnjaka odgovarajuće medicinske struke, i mišljenja Komisije za osobe s invaliditetom Zavoda za mirovinsko i invalidsko osiguranje. Dobivene podatke i dokumentaciju Ministarstvo nadležno za zdravstvo proslijeđuje komisijama koje svoje stručno mišljenje podnose u roku od tri mjeseca od primitka zahtjeva za mišljenje. Mišljenje Komisije za utvrđivanje uzročne veze mora uključivati procjenu o tomu je li šteta za zdravlje ili smrt neke osobe proizašla iz obveznog cijepljenja. Komisija za invalidnost

97 Ibid.

98 Odluka Ustavnog suda Republike Slovenije Op. cit. u bilj. 29., točka B. - III.

99 Zakon o nalezljivih boleznih - uradno prečiščeno besedilo - ZNB-UPB1 (Uradni list RS, št. 33/06 z dne 30. 3. 2006); dostupno na: https://www.uradni-list.si/glasilo-uradni-list-rs/ vsebina/72546, pristupljeno 15. studenog 2017.

100 Sukladno članku 53. c iznos naknade jednom godišnje vrednuje Ministarstvo nadležno za zdravstvo, sukladno podatcima Državnog zavoda za statistiku Republike Slovenije na razini godišnje inflacije.

101 Sukladno članku 53. č zahtjev mora sadržavati ime i prezime osobe koja je cijepljena, ime i prezime osobe koja traži pravo na naknadu, naziv i sjedište zdravstvene ustanove ili druga pravna ili fizička osoba u kojoj je provedeno cijepljenje, podatke i dokumentaciju o cijepljenju i navodne posljedice cijepljenja (npr. datum cijepljenja, zarazna bolest protiv kojih je provedeno cijepljenje, sumnje na posljedice cijepljenja, dokumentacija o liječenju navodnih posljedica cijepljenja itd.). 
daje mišljenje o tomu jesu li oštećenoj osobi ozbiljno i trajno otežane životne funkcije. U roku od 30 dana od primitka mišljenja komisija ministar nadležan za zdravstvo donosi rješenje. Protiv toga rješenja ne postoji žalba, ali je moguć upravni spor. Naknada se isplaćuje iz državnog proračuna bez obzira na krivnju, budući da je istim Zakonom određena objektivna odgovornost države. ${ }^{102}$

\subsection{Republika Hrvatska - izvansudski program naknade štete uzrokova- ne cijepljenjem - protiv bolesti kvrgave kože goveda}

Da svaki lijek, pa tako i cjepivo, ponekad uzrokuje nuspojave već je općepoznata činjenica. Kao što je supra opisano, u nizu se država u slučajevima težih nuspojava zbog cijepljenja priznaje oštećenicima i/ili njihovoj obitelji pravo na naknadu i to izvansudskim putem, koji je brži i jednostavniji od parničnog postupka. Prednosti takvih programa nisu ostali u potpunosti neprepoznati niti u Republici Hrvatskoj, gdje sličan program postoji, ali barem za sada, samo ako su u pitanju domaće životinje. Naime, cijepljenje goveda protiv bolesti kvrgave kože u Republici Hrvatskoj provedeno je u razdoblju od kolovoza do studenog 2016. godine. Uginuće goveda, drastičan pad proizvodnje mlijeka i problemi s plodnosti samo su neke od posljedice tog preventivnog postupka. Temeljem članka 34. Zakona o veterinarstvu ${ }^{103} \mathrm{za}$ životinju koja je uginula zbog provedbe naređene mjere, posjednik životinje ima pravo na naknadu štete u visini tržišne cijene na dan provođenja mjere. Sukladno Uputi Ministarstva poljoprivrede - uprave za veterinarstvo i sigurnost hrane od 26. kolovoza 2016. godine o načinu postupanja kod nuspojava nastalih kao posljedica aplikacije cjepiva protiv bolesti kvrgave kože, nuspojave se prijavljuju nadležnom veterinarskom inspektoru koji potom zahtjev za naknadu štete podnosi Ministarstvu poljoprivrede - Upravi za veterinarstvo i sigurnost hrane. ${ }^{104}$

Prema priopćenju Ministarstva poljoprivrede Republike Hrvatske objavljenom 4. svibnja 2017. godine na službenim internetskim stranicama mljekarima je zbog toga isplaćeno 19 milijuna kuna naknade štete od čega je 3,3 milijuna kuna isplaćeno za naknadu izravnih posljedica cijepljenja - uginuća 509 goveda. ${ }^{105}$

Možemo zaključiti da u Republici Hrvatskoj postoji neosporno pravo na izvansudsku naknadu štete zbog nuspojava cijepljenja domaćih životinja, dok takvog načina obeštećenja u slučaju nuspojava zbog obveznog cijepljenja djece nema. Stoga bi de lege ferenda valjalo makar uzeti u obzir mogućnost uvođenja sličnog programa

102 Zakon o nalezljivih boleznih - uradno prečiščeno besedilo - ZNB-UPB1 (Uradni list RS, št. 33/06 z dne 30. 3. 2006), članci 53. a do 53. f; dostupno na: https://www.uradni-list.si/glasilouradni-list-rs/vsebina/72546, pristupljeno 15. studenog 2017.

103 Zakona o veterinarstvu, Narodne novine, br. 82/13., 148/13.

104 Uputa Ministarstva poljoprivrede - uprave za veterinarstvo i sigurnost hrane od 26. kolovoza 2016. godine o načinu postupanja kod nuspojava nastalih kao posljedica aplikacije cjepiva protiv bolesti kvrgave kože; dostupno na: http://cijepljenje.info/wp-content/uploads/2016/09/ postupanje.kod_.nuspojava.uputa_.pdf, pristupljeno: 10. studenog 2017.

105 Ministarstvo poljoprivrede, dostupno na: http://www.mps.hr/hr/novosti/mljekarimaisplaceno-19-milijuna-kuna-naknade-zbog-cijepljenja-zivotinja-protiv-bolesti-kvrgave-koze, pristupljeno 12. studenog 2017. 
i kada su u pitanju ljudi, djeca. Program bi, prema iskustvima zemalja koje ga imaju već više godina, svakako utjecao na ubrzavanje postupka obeštećenja, smanjenje troškova, posebno ako je u pitanju dokazivanje uzročno posljedične veze, a i razina povjerenja u sam postupak imunizacije bila bi podignuta na višu razinu.

\section{ZAKLJUČAK}

Države danas obvezivanje na cijepljenje, koje većina pripadnika medicinske zajednice smatra učinkovitom mjerom sprječavanja širenja zaraznih bolesti, temelje na obvezi zaštite zdravlja građana. ${ }^{106}$

Moglo bi se reći da je pojavnost štetnih nuspojava cijepljenja već dobro poznata činjenica, iako je šire upoznavanje primatelja zdravstvenih usluga s njom tek odnedavno započelo. Jedan od glavnih razloga "čuvanja tajne" strah je od demotivacije za cijepljenje. Prihvaćanje informiranog pristanka prije cijepljenja pomaže u postizanju ciljeva postavljenih imunizacijskim programima i omogućava njihovo provođenje uz smanjeni rizik od eventualne tužbe. Davanje izjave o informiranom pristanku na cijepljenje i obaviještenosti o mogućim nuspojavama na propisanim obrascima nužna je pretpostavka činjenja ovoga preventivnog zdravstvenog tretmana. Ipak, u državama gdje je cijepljenje obvezatno, davanje informiranog pristanka ostaje samo na deklaratornoj razini jer legalnih mogućnosti odbijanja ovoga preventivnog medicinskog zahvata gotovo da i nema. S druge strane, države koje osobama ostavljaju pravo izbora, ali ih pritom sveobuhvatnom edukacijom i pružanjem potpunih informacija potiču na dobrovoljno cijepljenje, često ostvaruju i bolje rezultate po broju opće procijepljenosti. Ovakva politika nije samo etički prihvatljiva nego može doprinijeti i uštedi na potraživanjima naknade štete. ${ }^{107}$

Nadalje, ako ipak dođe do teže nuspojave cijepljenja, oštećenici u nizu država imaju pravo tražiti obeštećenje putem izvandsudskih programa naknade štete, kojima se, u odnosu na parnicu, ubrzava i pojednostavljuje taj postupak. Argumenti koji podupiru uvođenje programa naknade štete zbog cijepljenja uključuju političke i ekonomske pritiske, opasnost od dugotrajnih i skupih parničnih postupaka, povećanje povjerenja u programe cijepljenja, posebno kada je propisano kao obvezno, i osiguranje održivosti opskrbe cjepivom. Osim toga, sheme naknada također se temelje na načelu pravičnosti. ${ }^{108}$

Uvođenje izvansudskih programa naknade štete zbog nuspojava cijepljenja de lege ferenda u Republici Hrvatskoj više je nego opravdano budući da de lege lata hrvatski zakoni adekvatno ne uređuje državnu odgovornost za štetu koju pojedinac može imati zbog cijepljenja na koje ga je ta ista država zakonski obvezala. ${ }^{109}$ Kao što

106 Tucak Op. cit. u bilj. 30., str. 160.

107 Ibid.

108 Op. cit. (Looker, C., Kelly) u bilj. 6.

109 Zbog istog je razloga slovenski Ustavni sud naložio Parlamentu da u roku od godine dana ispravi navedeni nedostatak. Odluka Ustavnog suda Republike Slovenije Op. cit. u bilj. 29..; Tucak, I., Legal and Ethical Justification of Compensation Regarding Compulsory Vaccination Injuries. In: Bacher, U. et al. (ur.), Interdiscplinary Management Research, Ekonomski fakultet u Osijeku \& Hochschule Pforzheim University of Applied Sciences, 2016., str. 783-800, str. 794. 
se u recentnoj znanstvenoj literaturi iznosi, civilizirano društvo je obvezno nadoknaditi štetu do koje je došlo zbog obveznog cijepljenja ili cijepljenja povezanog s određenim profesijama. ${ }^{110}$

Programi naknade štete zbog nuspojava cijepljenja u zemljama koje su ih usvojile, usmjereni su ponajprije na pravednu i učinkovitu naknadu radi odvlačenja potencijalnih tužitelja od nepredvidljivih i teških sudskih odštetnih parnica. Osim propisivanja iznosa odštete zbog nuspojava, ovi programi potiču i istraživanja u svrhu povećanja sigurnosti cjepiva, obvezuju na prijavljivanje štetnih nuspojava cijepljenja i ukazuju na nužnost davanja potpunih informacija o prednostima i nedostatcima cijepljenja kao preventivnog medicinskog postupka. U SAD-u je ponajprije osmišljen kako bi se obeshrabrilo podnošenje odštetnih zahtjeva u korist sigurnije i brže, iako manje velikodušne, naknade. ${ }^{11}$

Da se i u Republici Hrvatskoj uočavaju prednosti izvansudskih načina naknade štete koja je prouzročena cijepljenjem dokaz je postojanje sličnih programa kada je u pitanju obeštećenje posjednika domaćih životinja. Naime, zbog nuspojava cijepljenja posjednik životinje ima pravo na naknadu štete u visini tržišne cijene na dan provođenja mjere. Sukladno Uputi Ministarstva poljoprivrede - uprave za veterinarstvo i sigurnost hrane, takvo je obeštećenje i provedeno nakon niza nuspojava nakon cijepljenja goveda protiv bolesti kvrgave kože. Stoga se postavlja pitanje, ne bi li trebalo i roditeljima djece oštećene zbog nuspojava cijepljenja, koje je u velikom broju slučajeva u Republici Hrvatskoj i obvezno, omogućiti da do obeštećenja dođu izvansudskim putem pred stručnim tijelom? Alternativne metode rješavanja sporova daju oštećenicima dodatnu mogućnost opredjeljenja za nove načine rješavanja sporova, čime im olakšavaju put postizanja obeštećenja.

Posljednjih godina, budući da je, s jedne strane, u predškolskoj i školskoj dobi propisana obveza za veliki broj cjepiva protiv zaraznih bolesti, a s druge strane, ako dođe do štetne nuspojave, ne postoji jasno uređen okvir odgovornosti, dolazi do nepovjerenja u sustav i stvaranje otpora cijepljenju. Dakle, program bi bio koristan i zbog jasnog definiranja okvira odgovornosti države u slučaju da nešto, što je nametnula pod prijetnjom kazne, pođe po krivu, a bilo bi poželjno i zbog jačanja povjerenja $u$ imunizaciju.

Nadalje, u današnje vrijeme sve je veća tendencija usmjeravanja potencijalnih tužitelja na mirno rješavanje sporova, a programi izvansudske naknade štete zbog nuspojava cijepljenja upravo su jedan od oblika mirnog rješavanja mogućeg spora. Sukladno Zakonu o parničnom postupku, kada je tuženik Republika Hrvatska, postoji i zakonska obveza pokušaja mirenja, koja je čak i procesna pretpostavka za podnošenje tužbe sudu. Mirenje se u tom slučaju de lege lata provodi pred nadležnim državnim odvjetništvom. Zbog realne potrebe sudjelovanja medicinskih i drugih stručnjaka u

110 Op. cit. (Mello) u bilj. 2., str. 42.; Tucak, I., Legal and Ethical Justification of Compensation Regarding Compulsory Vaccination Injuries, Facta Universitatis, Law and Politics, vol. 15., br. 2., 2017., str. 145-155, str. 154.

111 Cilj je, prema svemu sudeći, postignut. Godine 1986. protiv jednog proizvođača cjepiva podignuto je 250 tužbi, a nakon toga, do 1997. podignuto je svega četiri tužbe. V. Breen, E. A., One Shot Deal: The National Childhood Vaccine Injury Act, Wm. and Mary L. Rev., vol. 41., br. 84., 1999., str. 319. 
ovim postupcima, de lege ferenda bilo bi poželjno kada bi se neki oblik mirenja vodio pred stručnom komisijom. Pri oformljivanju tijela koje provodi program naknade štete trebalo bi voditi računa o zastupljenosti stručnjaka iz različitih područja, budući da probleme koji se pojavljuju u pružanju zdravstvene usluge, drukčije promatraju liječnici, socijalni radnici, farmaceuti ili pravnici, što njihovo rješavanje čini iznimno složenim zbog potrebe za pomirenjem tih različitih poimanja vrijednosti. Osim toga, de lege lata, navedena obveza mirenja postoji samo ako je tuženik Republika Hrvatska, dok drugi potencijalni tuženici nisu obuhvaćeni tom obvezom. Ipak, treba imati na umu da su programi naknade štete u pravilu alternativni načini obeštećenja. Većina zemalja koje imaju programe naknade još od njegovog uvođenja dopuštaju podnositeljima zahtjeva pokretanje građanske tužbe za naknadu štete uz ili umjesto programa. ${ }^{12}$ Iako je u pravilu stajalište prakse i znanosti da privremeno ograničavanje prava na podnošenje tužbe sudu prije pokušaja rješavanja spora nekim oblikom mirenja ne ugrožava temeljno ljudsko pravo na pristup sudu, ${ }^{113}$ ako se isti cilj može postići blažim sredstvom, primjerice obvezom snošenja troškova postupka bez obzira na uspjeh u parnici, ako se spor mogao riješiti i izvansudski, a stranka je tu mogućnost nerazumno odbila, tada bi to sredstvo trebalo imati prioritet. ${ }^{114}$

Naime, mirenje, pa tako i ovo u obliku programa naknade štete zbog nuspojava cijepljenja, kao procesna pretpostavka dopuštenosti podnošenja tužbe, u odnosu na obvezu snošenja parničnih troškova, veći je oblik ograničenja prava na pristup sudu. Stoga, budući da je moguće ostvarivanje jednakih ciljeva i sankcijom u obliku plaćanja parničnih troškova, takvom bi načinu poticanja stranaka na izvansudsko rješenje spora trebalo dati prednost. ${ }^{115}$

112 Npr. Danska, Francuska, Njemačka, Italija, Japan, Norveška, Quebec, Švicarska, Tajvan i Ujedinjeno Kraljevstvo. V.: Mariner, W. K., Compensation Programs for Vaccine-related Injury Abroad: A Comparative Analysis, St. Louis U. L. J., vol. 31., 1987., str. 612.; Evans, G., Vaccine Injury Compensation Programs Worldwide, Vaccine, vol. 17., 1999., str. 25-26.

113 V. primjerice presudu Europskog suda za ljudska prava u predmetu Prince Hans-Adam II of Liechtenstein v. Germany, Application no. 42527/98, od 12. srpnja 2001. godine i presudu Suda Europske unije u predmetu Rosalba Alassini v. Telecom Italia SpA (C-317/08).

114 Knol Radoja, K., Obvezno mirenje-osvrt na rješenja iz komparativnog $i$ hrvatskog prava, Pravni vjesnik, vol. 31., br. 2., 2015., str. 111-130, str. 125.

115 Ibid. 


\section{LITERATURA}

1. Fine, P., Eames, K., Heymann, D. L., Clinical Infectious Diseases, vol. 52., br. 7., 2011., str. 911.-916.

2. Mello, M. M., Rationalizing Vaccine Injury Compensation, Bioethics, vol. 22., br. 1., 2008., str. 32.-42.

3. Fine, P., Eames, K., Heymann, D. L., Herd Immunity: A Rough Guide, Clin. Infect. Dis., vol. 52., br. 7., 2011., str. 911.-916.

4. Silverman, R. D., May, T., Private Choice Versus Public Health: Religion, Morality, and Childhood Vaccination Law, U. Md. L. J. Race Relig. Gender \& Class, vol. 1., 2001., str. 205.-521.

5. Looker, C., Kelly, H., No-fault Compensation Following Adverse Events Attributed to Vaccination: A Review of International Programmes, Bulletin of the World Health Organization, 2011., str. 371.-378.; dostupno na: http://www.who.int/bulletin/ volumes/89/5/10-081901/en/, pristupljeno: 29. rujna 2017.

6. Keelan, J., Wilson, K., Balancing Vaccine Science and National Policy Objectives: Lessons From the National Vaccine Injury Compensation Program Omnibus Autism Proceedings, Am. J. Public Health, vol. 101., br. 11., 2011., str. 2016.-2021.

7. Evans, G., Vaccine injury compensation programs worldwide, Vaccine, vol. 17., Supplement 3., 1999., str. 25.-35.

8. Field, R. I., Caplan, A. L., A Proposed Ethical Framework for Vaccine Mandates: Competing Values and the Case of HPV, Kennedy Institute of Ethics Journal, vol. 18, br. 2, 2008., 111.-124.

9. Davis, T. C., Fredrickson, D. D., Arnold, C. L., Cross, J. T., Humiston, S. G., Kristen Green, K. W., Bocchini, J. A., Childhood Vaccine Risk/Benefit Communication in Private Practice Office Settings: A National Survey, Pediatrics, vol. 107., br. 2., 2001., 1.-11.

10. Hendrix, K. S., Lynne A. Sturm, L. A., Gregory D. Zimet, G. D., Meslin, E. M., Ethics and Childhood Vaccination Policy in the United States, Am. J. Public Health, vol. 106., br. 2., 2016., str. 273.-278.

11. Salmon, D. A., Teret, S. P., MacIntyre, C. R., Salisbury, D., Burgess, M. A., Halsey, N. A., Compulsory Vaccination and Conscientious or Philosophical Exemptions: Past, Present and Future, Lancet, 2006.; dostupno na: https://www.r esearchgate.net/ publication/7315037_Compulsory_vaccination_a nd_conscientious_or_philosophical_ exemptions_Past_present_an d_future, pristupljeno 23. listopada 2017.

12. Salmon, D. A., Mandatory Immunization Laws and the Role of Medical, Religious and Philosophical Exemptions, dostupno na: http://www.vaccinesafety.edu/ exemptreview101503.pdf, pristupljeno 23. listopada 2017.

13. Tucak, I., Obvezno cijepljenje djece: za i protiv, u: Rešetar, B., Aras Kramar, S., Lucić, N., Medić, I., Šago, D., Tucak, I., Mioč, P., Suvremeno obiteljsko pravo i postupak, Pravni fakultet u Osijeku, Osijek, 2017., str. 137.-165.

14. Bilić, V., Alternativno rješavanje sporova i parnični postupak, doktorska disertacija, Zagreb, 2008.

15. Knol Radoja, K., Alternativno rješavanje medicinskih sporova, u: Mićović, M. (ur.)., Zbornik XII. Međunarodnog majskog savjetovanja "Usluge i uslužna pravila", Kragujevac, 2016., str. 589.-608.

16. Morrison, G., Robson, R., ADR in Healthcare: The Last Big ADR Frontier?, dostupno na: http://www.mediate.com/articles/robmorr1.cfm, pristupljeno: 3. ožujka 2016.

17. Danzon, P. M., The swedish patient compensation system: myths and realities, International Review of Law and Economics, vol. 14., 1994., str. 453.-466.

18. Davis, P. R., Lay-Yee, J. F. P. Hider, R. Briant, S. Schug, Compensation for Medical Injury in New Zealand: Does "No-Fault" Increase the Level of Claims Making and Reduce Social and Clinical Selectivity?, J. Health Polit Policy Law, vol. 27., 2002., str. 833. -854 . 
19. Mariner, W. K., National Vaccine Injury Compensation Program, Health Affairs, vol. 11., br.1., 1992., str. 255.-265.

20. Plotkin, S. A., Lessons learned concerning vaccine safety, Vaccine, vol. 20., suppl. 1., 2001., str. 16. -19 .

21. Weiler, P. C., Hiatt, H. H., Newhouse J. P., et al., A Measure of malpractice: medical injury, malpractice litigation, and patient compensation, Cambridge, Mass., Harvard University Press, 1993.

22. Mehlman, M. J., Resolving the medical malpractice crisis: Fairness considerations, Faculty Publications, 2003.

23. Balinska, M. A., Vaccination in tomorrow's society, Lancet Infect Diseases, vol. 3., br. 7., 2003., str. 443.-447.

24. Larson, H. J., Figueiredo, A., Xiahong, Z., Schulz, W. S., Verger, P., Johnston, I. G., Cook, A. R., Jones, N. S., The State of Vaccine Confidence 2016: Global Insights Through a 67-Country Survey, EBioMedicine, vol. 12., 2016., str. 295.-301., dostupno na: https://www.ncbi.nlm.nih.gov/pmc/articles/PMC5078590/, pristupljeno: 20. veljače 2018.

25. Parmet, W. E., Informed Consent and Public Health: Are They Compatible When it Comes to Vaccines?, Journal of Health Care Law \& Policy, vol. 8., br. 1, 2005., str. 71. -110 .

26. Hiroki Nakatani, Tadashi Sano, Tsutomu Iuchi, Review. Development of Vaccination Policy in Japan: Current Issues and Policy Directions., Jpn. J. Infect. Dis., vol. 55., 2002., str. 101.-111.

27. Boncz I., Sebestyen A., Compensation for vaccine injury in Hungary, Lancet, vol. 367., br. 9517., 2006., str. 1144.

28. Sloan, F. A., The Economics of Vaccines, u: Danzon, P. M., Sean Nicholson, S.,The Oxford Handbook of the Economics of the Biopharmaceutical Industry, Oxford University Press, New York, 2012.

29. Evans G., Levine E. M., Saindon E. H., Legal issues, u: Plotkin S. A., Orenstein W. A., Offit P. A., Vaccines, Saunders Elsevier, Philadelphia, 2008.

30. Tucak, I., Legal and Ethical Justification of Compensation Regarding Compulsory Vaccination Injuries. u: Bacher, U. et al. (ur.), Interdiscplinary Management Research, Ekonomski fakultet u Osijeku \& Hochschule Pforzheim University of Applied Sciences, 2016., str. 783.-800.

31. Tucak, I., Legal and Ethical Justification of Compensation Regarding Compulsory Vaccination Injuries, Facta Universitatis, Law and Politics, vol. 15., br. 2., 2017., str. 145.- -155 .

32. Breen, E. A., One Shot Deal: The National Childhood Vaccine Injury Act, Wm. and Mary L. Rev., vol. 41., br. 84., 1999., str. 309.-332.

33. Mariner, W. K., Compensation Programs for Vaccine-related Injury Abroad: A Comparative Analysis, St. Louis U. L. J., vol. 31., 1987., str. 612.

34. Evans, G., Vaccine Injury Compensation Programs Worldwide, Vaccine, vol. 17., 1999., str. 25.-26.

35. Knol Radoja, K., Obvezno mirenje - osvrt na rješenja iz komparativnog $i$ hrvatskog prava, Pravni vjesnik, vol. 31., br. 2., 2015., str. 111.-130.

36. Direktiva Vijeća 85/374/EEZ od 25. srpnja 1985. o približavanju zakona i drugih propisa država članica u vezi s odgovornošću za neispravne proizvode (SL 1985., L 210, str. 29.)

37. Ustav Republike Hrvatske, Narodne novine, br. 56/90., 135/97., 113/00., 28/01., 76/10., $5 / 14$.

38. Zakon o zaštiti pučanstva od zaraznih bolesti, Narodne novine, br. 79/07., 113/08., 43/09.

39. Obiteljski zakon, Narodne novine, br. 116/03., 17/04., 136/04., 107/07., 57/11., 61/11., 25/13., 75/14., 5/15. 
40. Zakon o pravima pacijenata, Narodne novine, br. 37/08.

41. Zakon o lijekovima, Narodne novine, br. 76/13., 90/14.

42. Zakon o obveznim odnosima, Narodne novine, br. 35/05., 41/08., 125/11., 78/15.

43. Zakon o parničnom postupku, Narodne novine, br. 53/91., 91/92., 112/99., 129/00., 88/01., 117/03., 88/05., 2/07., 96/08., 84/08., 123/08., 57/11., 25/13., 89/14.

44. Kodeks medicinske etike i deontologije, Narodne novine, br. 55/08.

45. Strategija reforme pravosuđa za razdoblje od 2013. do 2018. godine, Narodne novine, br. $144 / 12$.

46. Protection against infection act (Infektionsschutzgesetz - IfSG), 1045; 20 July 2000. Berlin: Federal Law Gazette; 2000., dostupno na: http://www.rki.de/cln_162/ nn_217358/EN/Content/Prevention/Inf_Dis_Surveilla nce/inf_dis_down.html? nnn=true, pristupljeno: 30 . rujna 2017.

47. Dispositif de règlement amiable des dommages imputables à des vaccinations obligatoires (in French). Paris: Office National d'Indemnisation des Accidents Médicaux; 2004., dostupno na: http://www.oniam.fr/vaccinations.php, pristupljeno: 30. rujna 2017.

48. Act for the compensation of vaccination damages (Impfschadengesetz, BGBI nr. 371/1973) (in German). Vienna: Bundeskanzleramt; 1973., dostupno na: http:// www.ris.bka.gv.at/Ergebnis. wxe? Suchworte $=371 \% 2 F 1973 \& x=0 \& y=0 \& A b$ fra $\mathrm{ge}=$ Gesamtabfrage, pristupljeno: 30 . rujna 2017 .

49. The Danish Liability for Damages Act. Copenhagen: Patientforsikringen; 2010., dostupno na: http://www.patientforsikringen.dk/en/Love-og-Regler/Lov-omklage-ogerstatningsadgang/Behandlingsskader.aspx, pristupljeno: 30. rujna 2017.

50. The Undertaking (Indemnity rules). Stockholm: Lakemedelsforsakringen (LFF);2009., dostupno na: http://www.lakemedelsforsakringen.se/default.asp?id=10822\&ptid=, pristupljeno: 11. rujna 2017.+

51. Federal law from 18 December 1970 on communicable disease control (Epidemics act) 818.101. Berne: Federal Authorities of the Swiss Confederation;1970. dostupno na: http://www.admin.ch/ch/d/sr/c818_101.html, pristupljeno: 11. rujna 2017.

52. The Regulatory Reform (Vaccine Damage Payments Act 1979) Order 2002, Statutory Instrument 2002 no. 1592. London: Office of Public Sector Information; 2002., dostupno na: http://www.opsi.gov.uk/si/si2002/20021592.htm, pristupljeno: 11. rujna 2017.

53. Finnish Pharmaceutical Insurance Pool [Internet site]. Helsinki: Finnish Pharmaceutical Insurance Pool; 2011., dostupno na: http://www.lvp.fi/www/page/lvp_www_2090, pristupljeno: 11. rujna 2017.

54. Accident Compensation Act 1972, s. 2 amended by Accident Compensation Amendment Act 2001. Wellington: New Zealand Legislation; 2001., dostupno na: http://www.legislation.govt.nz, pristupljeno: 11. rujna 2017.

55. Cabinet order no. 197 on implementation of immunization law, Tokyo, 1948., dostupno na: http://hourei.ndl.go.jp, pristupljeno: 30. rujna 2017.

56. National Childhood Vaccine Injury Act. 1986, dostupno na: http://www.hrsa.gov/ vaccinecompensation/authorizinglegislation.pdf, pristupljeno: 30. rujna 2017.

57. Public Health Protection Act, RSQ, chapter S-2.2., dostupno na: http://legisquebec. gouv.qc.ca/en/ShowDoc/cs/S-2.2, pristupljeno: 11. rujna 2017.

58. Law no. 238 of 25 July 1997, modifications and additions to the Law no. 210 of February 251992 , relating to compensation to those harmed by mandatory vaccinations, blood transfusions and blood products, Rome: Ministry of Health; 1997., dostupno na: http:// www.normattiva.it, pristupljeno: 11. rujna 2017.

59. Patient Injury Act of 15 June 2001 no. 53, Oslo: Ministry of Health; 2001., dostupno na: http://www.lovdata.no/all/nl-20010615-053.html, pristupljeno: 11. rujna 2017.

60. Prevention of Contagious Diseases Act, Law 6162, Seoul: Korean Centers for Disease Control and Prevention; 2009., dostupno na: http://www.glin.gov/view. action?glinID=70100, pristupljeno: 11. rujna 2017. 
61. Hungarian Health Code (1997. CLIV), dostupno na: https://www.lexadin.nl/wlg/legis/ nofr/eur/lxwehun.htm\#Health\%20Law, pristupljeno: 11. rujna 2017.

62. Act on patient insurance no. 111/2000. Reykjavik: Ministry of Welfare; 2000., dostupno na: http://eng.velferdarraduneyti.is/acts-of-Parliament/nr/20366, pristupljeno: 11. rujna 2017.

63. National Vaccine Injury Compensation Program, dostupno na: https://www.in.gov/isdh/ files/VICP.pdf, pristupljeno 22. rujna 2017.

64. 42 U.S.C.A. § 300aa-21(b), dostupno na: https://www.law.cornell.edu/uscode/ text/42/300aa-21, pristupljeno 26. rujna 2017.

65. Zakon o nalezljivih boleznih-uradno prečiščeno besedilo- ZNB-UPB1 (Uradni list RS, št. 33/06 z dne 30. 3. 2006); dostupno na: https://www.uradni-list.si/glasilo-uradni-listrs/vsebina/72546, pristupljeno 15. studenog 2017.

66. Zakon o veterinarstvu, Narodne novine, br. 82/13., 148/13.

67. Uputa Ministarstva poljoprivrede-uprave za veterinarstvo i sigurnost hrane od 26. kolovoza 2016. godine o načinu postupanja kod nuspojava nastalih kao posljedica aplikacije cjepiva protiv bolesti kvrgave kože; dostupno na: http://cijepljenje.info/ wp-content/uploads/2016/09/postupanje.kod_.nuspojava.uputa_.pdf, pristupljeno: 10 . studenog 2017.

68. Ministarstvo poljoprivrede, dostupno na: http://www.mps.hr/hr/novosti/mljekarimaisplaceno-19-milijuna-kuna-naknade-zbog-cijepljenja-zivotinja-protiv-bolestikvrgave-koze, pristupljeno 12. studenog 2017.

69. Rješenje Ustavnog suda Republike Hrvatske br.: U-I-5418/2008 od 30. siječnja 2014.

70. Odluka Ustavnog suda Republike Slovenije, U-I-127/01, Uradni list RS 25/2004., dostupno na: https://www.uradni-list.si/glasilo-uradni-list-rs/vsebina/2004-01-1089/ odlocba-o-ugotovitvi-da-prva-alineja-prvega-odstavka-22--clena-4--tocka-prvegaodstavka-57--clena-in-drugi-odstavek-57--clena-zakona-o-nalezljivih-boleznih-nisov-neskladju-z-ustavo-in-o-ugotovitvi-neskladnosti-zakona-o-nalezljivih-boleznih-zustavo; pristupljeno: 25. studenog 2017.

71. Presuda Vrhovnog suda Republike Hrvatske br. Rev 79/07-2 od 10. lipnja 2009.

72. Primjeri nekoliko stranih i domaćih presuda dostupni su na: http://www.cijepljenje.info/ pravni-kutak/presude/, pristupljeno: 15. studenog 2017.

73. Odluka VSRH br. Gzp 170/08-8 od 21. prosinca 2009. godine

74. Presuda Vrhovnog suda Republike Hrvatske br. Rev 785/05-2 od 22. ožujka 2006. godine

75. Presuda Suda Europske unije C621/15, W and Others $v$ Sanofi Pasteur MSD SNC, 21 June 2017.

76. Presuda Suda Europske unije u predmetu Rosalba Alassini v. Telecom Italia SpA (C317/08).

77. Prince Hans-Adam II of Liechtenstein v. Germany, Application no. 42527/98, od 12. srpnja 2001. godine

78. Stateoftheworld'svaccinesandimmunization,3rded.Geneva:WorldHealthOrganization; 2009.; dostupno na: http://whqlibdoc.who.int/publications/2009/9789241563864_eng. pdf, pristupljeno: 23. studenog 2017.

79. Legal dictionary, dostupno na: http://legal-dictionary.thefreedictionary.com/ Informed+Consent, pristupljeno: 11. rujna 2017.

80. Hrvatski zavod za javno zdravstvo, dostupno na: https://www.hzjz.hr/sluzbaepidemiologija-zarazne-bolesti/nuspojave-cijepljenja-u-hrvatskoj/, pristupljeno 21. veljače 2018. 


\title{
Katarina Knol Radoja*
}

\author{
Summary
}

\section{VACCINE INJURY COMPENSATION}

The recommendation of the majority of medical experts is regular preventive protection from infectious diseases, primarily through vaccination. However, like any other medical procedure and this entails certain risks, which sometimes can be fatal. In this case, the damaged individual and/or his family members, under certain conditions, may be entitled to compensation. However, when the compensation is claimed by a court, injured parties face a long-lasting judicial proceedings and expensive process of proving the causal connection between damage in the form of illness or death and received vaccine. Apart from inconvenience to the injured party, these court proceedings often represent negative publicity and a huge financial burden to the defendant, which is why there were delays in the supply of vaccines. Therefore a number of states have designed compensation programmes for serious injury or death due to the side effects of vaccination. The aim of the research is therefore focused on the analysis and recommendation of the programme of compensation for damage due to side effects of vaccination as an alternative dispute resolution opposed to the long-lasting and expensive civil litigation, except for rationalization of costs and reductions of the workload of the courts. The introduction of a vaccine injury compensation programme in the Republic of Croatia is especially advisable because vaccination is legally mandatory. In other words, although patients in the Republic of Croatia have general right to an informed consent before a medical intervention, when it comes to preventive vaccination, they have no choice. Furthermore, by forming the body conducting the programme we should remain careful and compile it with professionals from different areas of interest so that they can objectively examine adverse event from all perspectives, without favoring one side.

Key words: Alternative Dispute Resolution, Vaccine Injury Compensation Program, Medical Disputes, Informed Consent.

* Katarina Knol Radoja, Ph. D., Assistant Professor, Faculty of Law, University of J. J. Strossmayerin Osijek; kknol@pravos.hr. 
Zussamenfassung

\section{ERSATZ DES DURCH DIE IMPFUNG VERURSACHTEN SCHADENS}

Diemeisten Ärzteempfehlenregelmäßige VorbeugungvonInfektionskrankheiten, vor allem durch die Impfung. Trotzdem trägt dieses medizinisches Verfahren, wie auch alle anderen, bestimmte Risiken, die manchmal fatal sein können. In diesem Fall sind der Geschädigte und/oder seine Familie unter bestimmten Voraussetzungen zum Schadenersatz berechtigt. Falls sie aber zum Schadenersatz durch das Gerichtverfahren zu erlangen versuchen, werden sie mit einem langen und teuren Verfahren der Nachweisung der Kausalität zwischen dem Schaden in Form der Krankheit oder des Todes und der bekommenen Impfung konfrontiert. Neben der Ungünstigkeiten für den Geschädigten rücken diese Verfahren auch den Schädiger in ein schlechtes Licht und stellen für ihn eine große finanzielle Belastung dar, weshalb sie oft zum Ausfall der Impfungsversorgung führen. Aus diesem Grund wurden in zahlreichen Staaten Programme des Schadenersatzes für schwere Verletzungen oder Tod wegen Nebenwirkungen der Impfung ausgearbeitet. Deshalb ist es das Ziel dieser Forschung diese Programme zu analysieren und ihre Empfehlungen zu erörtern, weil sie im Unterschied zum langen und teuren Zivilprozess einen alternativen Weg zum Schadenersatz darstellen. Außer wegen der Kostenrationalisierung und der Entlastung von Gerichten wird die Einführung von Programmen des Schadenersatzes wegen Nebenwirkungen der Impfung in der Republik Kroatien stark empfohlen, weil es hier für bestimmte Impfungen eine gesetzliche Impfpflicht besteht. Mit anderen Worten, obwohl die Patienten in der Republik Kroatien das Recht auf informierte Einwilligung vor einem medizinischen Eingriff haben, haben sie bei der Impfung keine Wahlfreiheit. Ebenfalls empfiehlt es sich, dass das für die Ausarbeitung des Programms zuständige Körper aus Experten in unterschiedlichen Bereichen besteht, so dass sie möglichst objektiver und aus allen Perspektiven den Schadenfall betrachten können, um die Begünstigung nur einer Partei zu vermeiden.

Schlüsselwörter: alternative Streitbeilegung, Programme des Schadenersatzes wegen Nebenwirkungen der Impfung, medizinische Streitigkeiten, informierte Einwilligung. 


\section{Riassunto}

\section{IL RISARCIMENTO DEL DANNO DA VACCINAZIONE}

La maggioranza degli esperti medici raccomanda la profilassi preventiva contro le malattie infettive mediante somministrazione di vaccini. Nondimeno, come ogni altra procedura medica, anche questa comporta determinati rischi, che in alcuni casi possono essere anche dall'esito fatale. In tale caso il singolo danneggiato e/o i membri della sua famiglia, a determinate condizioni, possono avere diritto al risarcimento del danno. Tuttavia, quando tentano di soddisfare le pretese risarcitorie per le vie giudiziali, si trovano a dovere affrontare un procedimento lungo e costoso volto a dimostrare il nesso di causalità tra il danno sotto forma di patologia o di decesso e la somministrazione del vaccino. A parte gli svantaggi a carico della parte danneggiata, questi procedimenti giudiziali spesso sono fonte di pubblicità negativa e di un grande peso finanziario anche per la parte convenuta, in ragione del quale è capitato che ci fosse un blocco delle forniture di vaccini. Per questo motivo in molti paesi sono stati ideati programmi di risarcimento del danno da gravi lesioni o da morte a causa degli effetti collaterali del vaccino. Lo scopo dell'indagine è pertanto concentrato sull'analisi e sul sostegno del programma di risarcimento del danno a seguito degli effetti collaterali del vaccino, quale, rispetto ad una lunga e costosa causa civile, metodo alternativo di risarcimento. Tranne che per la razionalizzazione dei costi e per lo sgravio dei tribunali, l'introduzione del programma di risarcimento del danno da effetti collaterali dei vaccini nella Repubblica di Croazia sarebbe opportuna anche per il fatto che ivi la vaccinazione è obbligatoria per legge. In altre parole, benché i pazienti nella Repubblica di Croazia abbiano il diritto generale al consenso informato prima di una qualsiasi procedura medica, quando si tratta di una procedura preventiva di vaccinazione non hanno diritto di scelta. Ancora, in occasione della costituzione dell'organo che segue i programmi occorre rimanere cauti e comporlo di esperti provenienti da diversi campi, affinché possano mantenere una visione oggettiva circa l'evento dannoso da tutte le prospettive, anziché favorire una sola delle parti.

Parole chiave: risoluzione alternativa delle controversie, programmi di risarcimento a causa degli effetti collaterali da vaccinazione, controversie mediche, consenso informato. 